\title{
Utilizing Immunocytokines for Cancer Therapy
}

\author{
Erin Runbeck $^{1}$, Silvia Crescioli $^{2}\left(\mathbb{D}\right.$, Sophia N. Karagiannis ${ }^{2}\left(\mathbb{D}\right.$ and Sophie Papa ${ }^{1, *(\mathbb{D}}$ \\ 1 ImmunoEngineering Group, School of Cancer and Pharmaceutical Studies, King's College London, \\ London SE19RT, UK; runbecke@email.chop.edu \\ 2 St. John's Institute of Dermatology, School of Basic and Medical Biosciences, King's College London, \\ London SE1 9RT, UK; silvia.crescioli@kcl.ac.uk (S.C.); sophia.karagiannis@kcl.ac.uk (S.N.K.) \\ * Correspondence: sophie.papa@kcl.ac.uk
}

check for

updates

Citation: Runbeck, E.; Crescioli, S.; Karagiannis, S.N.; Papa, S. Utilizing Immunocytokines for Cancer

Therapy. Antibodies 2021, 10, 10.

https://doi.org/10.3390/antib10010010

Received: 12 January 2021

Accepted: 22 February 2021

Published: 9 March 2021

Publisher's Note: MDPI stays neutral with regard to jurisdictional claims in published maps and institutional affiliations.

\begin{abstract}
Cytokine therapy for cancer has indicated efficacy in certain diseases but is generally accompanied by severe toxicity. The field of antibody-cytokine fusion proteins (immunocytokines) arose to target these effector molecules to the tumor environment in order to expand the therapeutic window of cytokine therapy. Pre-clinical evidence has shown the increased efficacy and decreased toxicity of various immunocytokines when compared to their cognate unconjugated cytokine. These anti-tumor properties are markedly enhanced when combined with other treatments such as chemotherapy, radiotherapy, and checkpoint inhibitor antibodies. Clinical trials that have continued to explore the potential of these biologics for cancer therapy have been conducted. This review covers the in vitro, in vivo, and clinical evidence for the application of immunocytokines in immuno-oncology.
\end{abstract}

Keywords: antibody; antibody engineering; immunocytokine; immunotherapy; cytokines; cancer therapy

\section{Introduction}

For most of the 20th century, the role of the immune system in cancer was debated. It is now understood that the immune system is involved in the control of malignancy through 'immunosurveillance' [1]. Early studies indicated the importance of cytokines in this process as effector and co-stimulatory molecules. A report using fibrosarcoma cells expressing a dominant negative interferon- $\gamma$ (IFN- $\gamma$ ) receptor, thus rendering the cells IFN- $\gamma$-insensitive in immunocompetent mice resulted in a loss of tumor control in the model [2]. Additionally, the discovery of interleukin 2 (IL-2) and its role in T cell expansion enabled ex vivo culture and expansion of T cells in a therapeutic context [3,4]. Interleukin 2 enhanced the cytotoxic potential of lymphocytes in two different syngeneic tumor models, thus prolonging subject survival, when lymphocytes were cultured with or injected simultaneously with IL-2 [5,6].

Tumor necrosis factor (TNF) has been approved for clinical use in Europe for isolated limb perfusions of sarcoma patients in conjunction with the chemotherapeutic agent melphalan. An initial trial of 23 patients treated with IFN- $\gamma$ and TNF yielded an $89 \%$ complete response rate with high grade hematological toxicity in two patients [7]. A subsequent larger study had a similar high response rate of 153/186 patients resulting in limb salvage for previously unresectable tumors. Grade 4 regional adverse effects occurred in 14 patients, and grade 3-4 hepatic and cardiovascular toxicity occurred in 17 and 6 patients, respectively [8].

To date, only interferon- $\alpha$ (IFN- $\alpha)$ and IL-2 have been approved by the Food and Drug Administration (FDA) for cancer treatment [9]. Clinical trials showed that IFN- $\alpha 2 b$ had a response rate of $57 / 64$ patients with hairy cell leukemia and $6 / 20$ and 40/114 patients with Kaposi's sarcoma in two separate studies [10-12]. The treatment of cutaneous melanoma with high dose IFN- $\alpha 2 b$ resulted in a median survival time of 3.82 years versus the control at 2.78 years [13]. A combination of chemotherapy and IFN- $\alpha 2 b$ in follicular lymphoma 
yielded an overall response rate of 104/123 patients compared to 82/119 patients in the chemotherapy-only arm [14]. However, the IFN- $\alpha$ therapy required a decrease in dosage or the cessation of treatment due to hematological, neurological, and hepatic toxicities [12-14].

Interleukin 2 administration resulted in objective response rates of $14 \%$ and $16 \%$ in metastatic renal cell carcinoma (mRCC) and metastatic melanoma patients, respectively $[15,16]$. Similar to IFN- $\alpha$, IL-2 was found to have high rates of dose-limiting toxicities. Interleukin 2 treatment exhibited high grade cardiovascular, gastrointestinal, neurological, pulmonary, hepatic, renal, and hematological toxicities, and it led to deaths in $4 \%$ and $2 \%$ of mRCC and metastatic melanoma patients, respectively $[15,16]$. A trial combining systemic IL-2 with autologous 'lymphokine activated killer' (LAK) cells showed no significant increase in survival or responses in patients given both LAK cells and IL-2 compared to IL-2 alone. Additionally, IL-2 infusion was associated with high levels of severe toxicity, as highlighted by a $3.3 \%$ treatment related mortality rate [17]. These clinical trials for IL-2, TNF, and IFN- $\alpha$ illustrated the necessity to establish a less toxic method of cytokine therapy with a wider therapeutic window.

With the introduction of hybridoma technology [18], it became possible to create large libraries of monoclonal antibody-producing clones in order to specifically target antigens of interest. The evolution of recombinant antibody technology led to the phage display method that offers fully humanized antibodies independent of the host's immune response [19-22]. Utilizing recombinant antibody production, payloads can be conjugated to antibodies and directed towards tumor-associated antigens (TAAs) for targeted therapy. As a method of targeted cytokine delivery, antibody-cytokine fusion molecules termed 'immunocytokines' (Figure 1) have been widely developed and assessed in clinical trials involving a variety of cancers and inflammatory conditions. They are composed of a targeting-antibody moiety, an amino acid linker, and a cytokine payload. Given the toxicity profiles of many systemically delivered cytokines, the use of an immunocytokine approach can often broaden the therapeutic window of the cytokine under study [23,24]. Initial reports showed the successful generation of immunocytokines containing lymphotoxin, TNF, granulocyte-macrophage colony-stimulating factor (GM-CSF), and IL-2 with direct and indirect anti-tumor capabilities in vitro [25-29]. An IL-2 immunocytokine targeting disialoganglioside (GD2) co-administered with LAK cells in a murine model for neuroblastoma resulted in the absence of detectable liver metastases. The injection of unconjugated recombinant human IL-2 (rhIL-2) at the same dosages as the immunocytokine was insufficient to abrogate liver metastases [30]. This field has since expanded to include different antibody formats, cytokines, combination regimens, and targeted indications. This review covers the evidence for immunocytokine therapy for the treatment of cancer.

Similar to monoclonal antibody therapy, the structure and size of the immunocytokine under investigation affects the performance of the drug. Full size antibody formats have increased circulation half-life and engage immune cells through the crystallizable fragment (Fc) portion of the molecule, retaining much of the antibody effector function within the immunocytokine [31,32]. However, immunocytokines utilizing antibody fragments also increase the half-life of the respective cytokine [24]. Smaller immunocytokine formats have a quicker clearance rate and greater tumor penetration [24,33]. Additionally, the structure of the cytokine payload can affect efficacy. An IL-12-based immunocytokine demonstrated an enhanced tumor retention and growth inhibition when expressed as a single chain variable fragment $(\mathrm{scFv})$ heterodimer connected by a disulfide bridge between the two subunits of IL-12 compared to a monomer consisting of both IL-12 subunits fused by a linker [34]. The intended effect of the immunocytokine and the native conformation of the delivered cytokine should be taken into consideration during engineering.

By targeting the antibody portion to the tumor-associated antigens presented on tumor cells, the immunocytokine is sequestered in the tumor microenvironment. Here, the functional cytokine can signal through its cognate receptors expressed on either/both tumor and immune cells and induce an anti-tumor response. An upward-facing arrow denotes an increase in activity, while a downward-facing arrow denotes a decrease. 


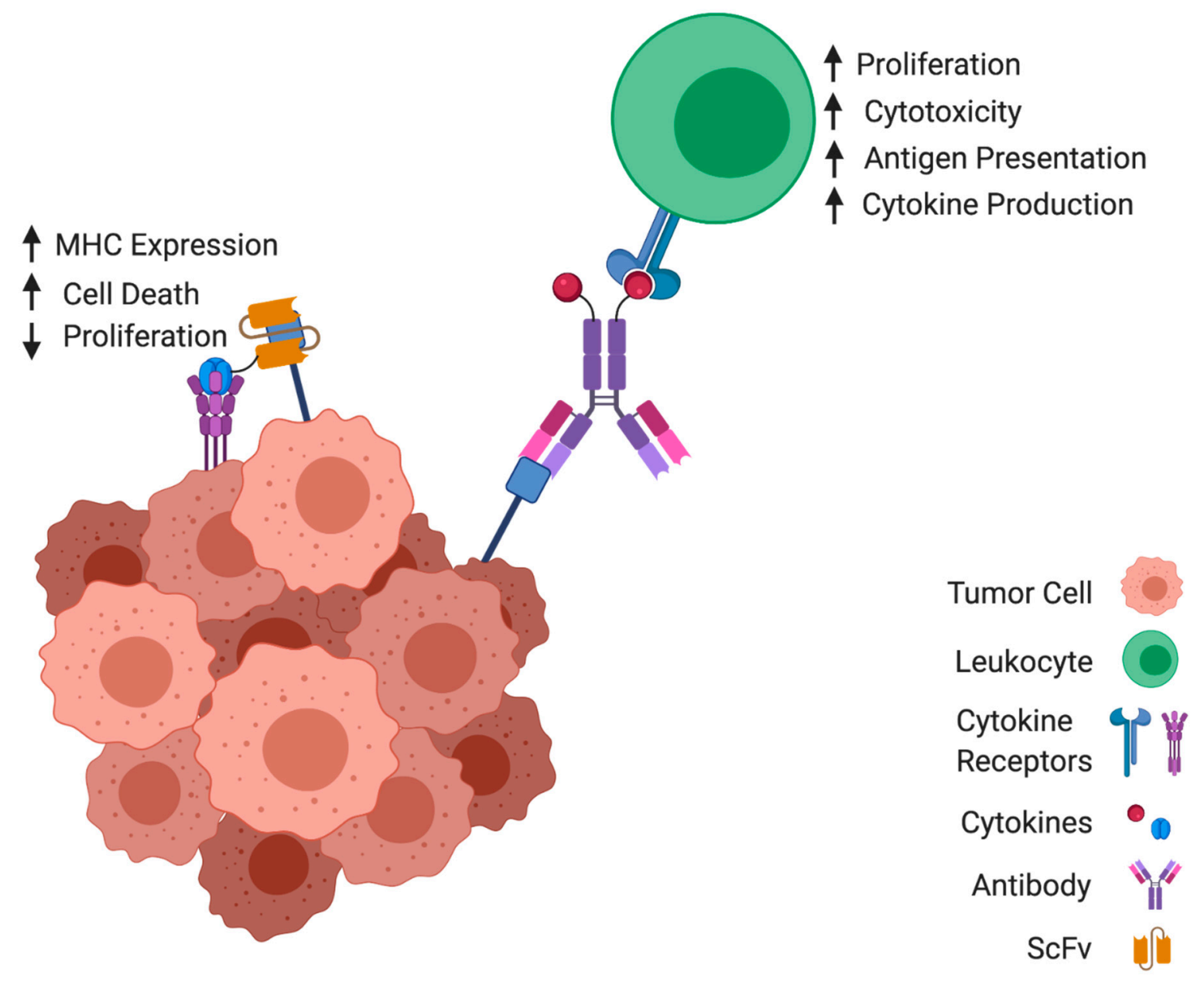

Figure 1. Concept of immunocytokine anti-cancer mechanism.

\section{Immunocytokines in Pre-Clinical Models}

Investigations have covered a multitude of different immunocytokine payloads and formats. In this section, previous reports of these antibody-fusion molecules will be addressed in the order of the delivered cytokine.

\subsection{Interleukin-2}

The most widely reported immunocytokines are IL-2-based. Interleukin-2 is a small protein primarily produced by activated $\mathrm{T}$ cells that increases proliferation and survival in an autocrine/paracrine fashion [35]. Based on the clinical evidence of unconjugated IL-2, targeted formats were developed to increase its therapeutic efficacy and safety. Early studies characterized the efficacy of IL-2 fused with an antibody specific for GD2 in models for melanoma and neuroblastoma [27,30,36-40]. In a murine model of metastatic melanoma, IL-2 immunocytokines targeting GD2 and epidermal growth factor receptor (EGFR) suppressed lung and liver metastases, in addition to prolonging survival, when administered after LAK cell reconstitution in immunocompromised mice. Unconjugated IL-2 and antibody injected after LAK cell reconstitution did not yield the same therapeutic effect [37]. In immunocompetent murine melanoma models, the immunocytokine anti-tumor response was dependent on $\mathrm{CD} 8^{+} \mathrm{T}$ cells and conveyed long-term protection against tumor rechallenge $[36,38,39]$. Later, it was determined that efficacy in pulmonary metastases models was also reliant on $\mathrm{CD}^{+} \mathrm{T}$ cell-dependent $\mathrm{CD} 40 / \mathrm{CD} 40$ ligand signaling [41]. Immunocytokine efficacy was demonstrated in neuroblastoma and, in contrast to the melanoma model, was dependent on natural killer (NK) cells and not T cells [30,40,42]. This was attributed to the neuroblastoma cell line secreting factors such as transforming growth factor- $\beta$ (TGF- $\beta$ ) 
and IL-10, which decreases T cell cytotoxicity, whereas select studies have shown IL-10 to increase NK cell activity in vivo $[42,43]$. Additionally, the intratumoral injection of GD2 or epithelial cell adhesion molecule (EpCAM)-targeting IL-2 immunocytokines increased the anti-tumor effect and immune cell presence in neuroblastoma and melanoma in vivo compared to intravenous administration and unconjugated IL-2 [44-47]. Both immunocytokines enhanced the formation of synapses between NK cells and melanoma or ovarian carcinoma, which was inhibited by an anti-IL-2 receptor $\alpha$ (IL-2R $\alpha$ ) antibody, suggesting that synapse formation was based on IL-2R engagement on NK cells by the cancer cell-bound immunocytokines [48].

Targets other than TAAs expressed on the cancer cells have been explored for IL-2 immunocytokine therapy. Immunocytokines have been designed to target the aberrant extracellular matrix (ECM) often found in the tumor micro-environment, which presents a more stable target in comparison to transformed cells. Different isoforms of fibronectin and tenascin-C are angiogenesis-related ECM proteins and show a tumor-vasculature restriction. Specifically, these vasculature TAAs are the extra-domain A (EDA) and extra-domain B (EDB) isoforms of fibronectin and the A1 domain isoform of tenascin-C (Tnc A1) [49-52]. An initial study investigating targeted IL-2 to EDB showed sufficient trafficking to the tumor vessels after intravenous administration and a significant reduction in tumor growth compared to saline, unconjugated IL-2, and parental antibody groups [23]. The delivery of IL-2 via EDA and Tnc A1 specificity showed efficacy at different dosages in acute myeloid leukemia (AML), non-small cell lung carcinoma (NSCLC), and teratocarcinoma models after intravenous or intratumoral injection; however, EDA-IL-2 was only effective when co-administered with an EDA-specific TNF immunocytokine [53-55]. Tumor control was dependent upon $\mathrm{NK}$ cell and $\mathrm{CD} 8^{+} \mathrm{T}$ cell presence, and immunocytokine treatment propagated an increase in $\mathrm{CD}^{+} \mathrm{T}$ cell proliferation and granzyme B secretion in the NSCLC tumors [53-55]. In the AML model, the immunocytokine caused a loss of weight in mice, but it was transient and did not require the cessation of treatment [54]. Interleukin-2 immunocytokines have been developed to target an array of antigens including prostatespecific membrane antigen (PSMA), programmed death ligand-1 (PD-L1), EGFR, carbonic anhydrase IX (CAIX), CD20, and DNA. As such, these immunocytokines increase the therapeutic window compared to unconjugated IL-2 and seem dependent on immune effector cells to illicit an anti-tumor response [31,56-61].

\subsection{Interferons}

Interferon- $\alpha$, a type I interferon with multiple subtypes displaying similar effects, was initially characterized for its antiviral properties. In the context of cancer, it exhibits direct and indirect anti-tumor effects through the dysregulation of tumor-promoting genes, the upregulation of suppressor genes and major histocompatibility complex I (MHC I), the inhibition of cell replication, sensitization for cell death, and the stimulation of immune cells $[62,63]$. A CD20-targeting immunocytokine utilizing the IFN- $\alpha 2$ subtype decreased the $50 \%$ inhibitory concentration $\left(\mathrm{IC}_{50}\right)$ compared to commercially available forms of IFN- $\alpha$, increased antibody-dependent cellular cytotoxicity (ADCC) against lymphoma cells (with a decreased complement-dependent cytotoxicity (CDC)), and prolonged survival in murine groups treated with the immunocytokine compared to equal concentrations of parental IFN- $\alpha$ and antibody [63]. A similar immunocytokine-targeting human leukocyte antigen DR (HLA-DR) demonstrated an enhanced ability to stimulate the apoptosis-promoting signal transducer and activator of transcription 1 (STAT1) pathway in multiple myeloma and lymphoma cells compared to the CD20-specific immunocytokine, but it also mediated toxicity against healthy peripheral blood mononuclear cells (PBMCs) [64]. A bispecific hybrid of these two immunocytokines exhibited a greater cytotoxicity in Daudi lymphoma cells than either monospecific original immunocytokine and a similar toxicity to the monospecific anti-HLA-DR immunocytokine [65].

Interferon- $\alpha$ has also been targeted to checkpoint molecule PD-L1. The in vivo production of the $\mathrm{T}$ cell tumor trafficking chemokine C-X-C motif chemokine ligand 10 (CXCL10) 
increased in murine lung cancer cells accompanied by retarded tumor growth with antiPD-L1-IFN- $\alpha$ compared to parental anti-PD-L1 and a non-specific immunocytokine [66]. Interferon- $\alpha$ immunocytokines targeting PD-L1 or CD20 demonstrated superior tumor control in lymphoma and colon cancer that was dependent on IFN- $\alpha$ receptor (IFNAR) expression in either the tumor cells or host immune cells $[67,68]$. In contrast, one group investigated an immunocytokine delivering IFN- $\alpha$ to the ECM protein EDA. It localized to the tumor and recruited immune cells but was no more effective at controlling the growth of teratocarcinoma or melanoma xenografts than a non-specific immunocytokine control. One possible explanation for this lack of efficacy is that increased IFN- $\alpha$ located in the perivasculature may deliver less of an anti-tumor response than if directly targeted to the tumor cells [69].

Interferon- $\gamma$ is a type II interferon produced by activated T cells and NK cells. It has anti-viral/anti-tumor characteristics and stimulates innate and adaptive immune responses [70]. Early studies exemplified the importance of IFN- $\gamma$ for inherent protection against tumor formation and progression. Investigations using transgenic mice lacking the crucial cell-mediated cytotoxicity molecules or receptors for IFN- $\gamma$ and perforin led to a higher rate of chemically-induced tumor development, the increased tumor growth of syngeneic xenografts, and an elevated proportion of metastases [71,72]. Targeting IFN- $\gamma$ to the tumor microenvironment via EDA or EDB resulted in enhanced tumor and liver metastasis control when compared to a non-specific IFN- $\gamma$ immunocytokine in teratocarcinoma models, sarcoma, and Lewis lung carcinoma (LLC) models. Increased numbers of CD4 ${ }^{+} \mathrm{T}$ cells, NK cells, macrophages, and granulocytes were observed in the tumors treated with targeted IFN- $\gamma$ with a decrease in regulatory T cells (Tregs). Both immunocytokines exhibited impeded tumor trafficking by the IFN- $\gamma$ receptor binding off-target tissues. Tumor specificity could be potentiated by saturating receptors with additional immunocytokine administration and no apparent effect on body weight [73,74].

Smaller antibody formats, such as single-domain variable heavy chain $(\mathrm{VHH})$ antibodies, with potentially greater tumor penetration, and more tumor restricted interferons such as IFN- $\lambda$ have also been explored in the context of immunocytokine therapy [61,75].

\subsection{Tumor Necrosis Factor}

The earliest reports of antibody-cytokine fusion molecules included TNF. Tumor necrosis factor is a pro-inflammatory cytokine expressed by macrophages, NK cells, T cells, and B cells. While studies have shown the anti-tumor effects of TNF administration, endogenous production can also promote tumor cell survival through its activation of transcription factor NF- $\mathrm{kB}$ and is expressed by various cancer cells types [76-80]. Due to its inflammatory potency, TNF is a good prospect for localized therapy and was initially targeted to the human transferrin receptor and GD2 with cytotoxicity in vitro in breast cancer cells and murine fibroblasts $[25,81,82]$. The tumor necrosis factor delivery to tumor microenvironment antigens such as EDA, EDB, and fibroblast activation protein (FAP) demonstrated growth inhibition in multiple models. Anti-FAP-TNF stimulated polymorphonuclear (PMN) cells to generate reactive oxygen species and human umbilical vein endothelial cells (HUVECs) to produce the clotting molecule tissue factor, which can cause necrosis and granulocyte infiltration, while anti-EDA-induced necrosis and NK cell infiltration $[53,83]$. Targeting TNF to EDB delayed tumor growth in teratocarcinoma models compared to untargeted cytokine, and the anti-cancer effect was amplified when coadministered with melphalan or an EDB-specific IL-12 immunocytokine [24,84]. Necrosis was seen when TNF was targeted to the described hypoxic marker CAIX along with growth inhibition and protection against rechallenge in $\mathrm{CAIX}^{+}$colon and renal cell carcinomabearing mice with q $3 \%$ decrease in body weight $[59,85]$. Tumor necrosis factor-resistance in a breast cancer cell line was overcome by a TNF immunocytokine targeting human epidermal growth factor 2 (HER-2) via the upregulation of TNF receptor 1 (TNFR1) expression, the activation of caspase-associated apoptosis, and the deactivation the Akt proliferation 
pathway $[86,87]$. Overall, TNF immunocytokines engage anti-tumor immunity through direct cytotoxicity and the induction of necrosis of tumor tissue.

\subsection{Interleukin-12}

Interleukin 12 is a heterodimeric cytokine produced by most leukocytes and skews immunity towards an anti-cancer $T$ helper cells type $1\left(T_{H} 1\right)$ effector response [88]. High systemic toxicity rates at low dosages of IL-12 led to its development for targeted delivery $[89,90]$. An early study of targeted IL-12 to EDB showed tumor growth control in colon carcinoma and, to a greater extent, teratocarcinoma models. This was accompanied by a $6 \%$ body weight loss and pathological findings in harvested liver tissue. There was an increased IFN- $\gamma$ and CXCL10 production in the tumor environment and an influx of $\mathrm{CD}^{+}, \mathrm{CD}^{+} \mathrm{T}$, and NK cells [90]. The modification of this particular immunocytokine's format indicated that a heterodimeric fusion protein containing two anti-EDB scFvs, linked by a natural disulfide bridge in the two subunits of IL-12, had greater tumor trafficking, retention, and efficacy in teratocarcinoma than the previous single scFv-IL-12 format [34]. Variability has also been observed with different linker lengths and sequences attaching IL-12 and IL-2, with specific linkers enhancing tumor localization and retention [91,92]. Targeting IL-12 to EDB and EDA has been efficacious in tumor models of teratocarcinoma, prostate cancer, colon cancer, and epidermoid carcinoma with an influx of inflammatory innate and adaptive leukocytes [93-95].

A well-described IL-12 immunocytokine includes an anti-DNA fragment-targeting portion in order to direct the cytokine to necrotic tumor tissue. The immunocytokine outperformed unconjugated IL-12 in delaying the progression of LLC, colon carcinoma, melanoma, and bladder cancer tumors. This anti-cancer response and the prolongation of survival was reliant on NK cells and $\mathrm{CD} 8^{+} \mathrm{T}$ cells, but not $\mathrm{CD} 4^{+} \mathrm{T}$ cells, and ultimately did not protect against rechallenge [96,97]. An analysis of the microenvironment showed a shift towards a more inflammatory cellular response comprised of an increase in the CD8/CD4 T cells:macrophage/myeloid-derived suppressor cell (MDSC) ratio, a decrease in intratumoral TGF- $\beta$, and an increase in the proliferation/activation of $\mathrm{CD} 4^{+}$and $\mathrm{CD} 8^{+}$ $T$ cells [97]. This immunocytokine has been trialed in dogs with malignant melanoma with $2 / 15$ partial responses and four experiencing grade $4-5$ toxicity [98].

\subsection{Interleukin-15}

Similar to IL-2, IL-15 induces proliferation in T cells. In contrast, IL-15 preferentially promotes the proliferation of cytotoxic $\mathrm{T}$ cells rather than Tregs and decreases activationinduced cell death (AICD) compared to IL-2. Furthermore, IL-15 promotes the differentiation and maintenance of memory T cells and NK cells [99]. Targeting IL-15 to EDB indicated stronger efficacy in teratocarcinoma and colon carcinoma models compared to non-specific immunocytokine in a $\mathrm{CD} 8^{+} \mathrm{T}$ cell-dependent manner [100]. Interleukin-15 is primarily effective through trans-presentation: it is bound to IL-15 receptor $\alpha$ (IL-15R $\alpha$ ) on the surface of monocytes, macrophages, and dendritic cells, which then bind to IL- $15 R \beta / \gamma \mathrm{c}$ on T cells and NK cells [101]. Because of this, most immunocytokine studies based on IL-15 have developed a recombinant cytokine, RLI, that encompasses IL-15 bound to a portion of the IL-15R $\alpha$ called the sushi domain. The trans-presentation immunocytokine caused the greater proliferation of PBMCs in vitro compared to anti-FAP-IL-15 and increased the cytotoxicity of T cells [102]. Targeting RLI to GD2 and CD20 indicated ADCC and CDC in neuroblastoma and lymphoma cells, reduced the number of liver metastases, and prolonged the survival of mice for up to 120 days in lymphoma models compared to parental proteins $[103,104]$.

\subsection{Granulocyte-Macrophage Colony-Stimulating Factor}

Granulocyte-macrophage colony-stimulating factor is an inflammatory cytokine involved in the maintenance and maturation of myeloid cells, and it stimulates dendritic cell and macrophage activity [105]. This cytokine has been employed for immunother- 
apeutic regimens such as the FDA-approved dendritic cell vaccine for prostate cancer, Provenge [106]. Early studies described GM-CSF immunocytokines with varying activity [82,107]. An anti-GD2 antibody conjugated to GM-CSF showed increased neuroblastoma cell lysis compared to an unconjugated antibody when incubated with PMN cells, and cell death was attributed to ADCC [108]. Targeting GM-CSF to HER-2 reduced colon carcinoma tumor growth in a syngeneic model, initiated a $\mathrm{T}_{\mathrm{H}}$ 2-type antibody response, and increased the antigen presentation of dendritic cells $[109,110]$. When targeting EDB, the immunocytokine was able to traffic to teratocarcinoma tumors and delay progression at repeated high doses compared with a non-specific immunocytokine [100]. The dual delivery of IL-2 and GM-CSF to EpCAM-expressing colon carcinoma in vivo resulted in less lung metastases at low doses, but the effect of the dual immunocytokine was not greater than the single cytokine-carrying molecules [111].

\subsection{Additional Cytokines}

Various cytokine payloads have been investigated, with the most common listed previously. Additional studies have described cancer immunocytokine therapy incorporating tissue factor, IL-4, IL-3, granulocyte colony-stimulating factor (G-CSF), IL-1 $\beta$, IL-6, IL-13, IL-17, IL-7, vascular endothelial growth factor (VEGF), C-C motif chemokine ligand 21 (CCL21), and 4-1BBL [95,112-124].

\subsection{Variants}

Because of the potency of some inflammatory cytokines and the toxicity reported in trials, an added measure to increase safety and efficacy in immunocytokines is the use of variant cytokines. A point mutation in the IL-2 sequence responsible for binding endothelial cells, and thus off-target toxicity, resulted in a modest decrease of the binding of the high affinity receptor (IL-2R $\alpha$ ) expressed on T cells and a dramatically decreased binding of the intermediate affinity receptor expressed on other tissues. This led to preferential proliferation in T cells over NK cells and a 20-fold reduction in toxicity compared to the wild type [125]. In contrast, a carcinoembryonic antigen (CEA)-targeting IL-2 variant with diminished IL-2R $\alpha$ binding, and thus preferential IL-2R $\beta$ association that is predominant on cytotoxic T cells, was developed to reduce Treg response and off-target receptor binding. Proliferation in Tregs was greatly reduced in the IL-2 mutant compared to the wild type, with no difference in $\mathrm{CD}^{+} \mathrm{T}$ cell or NK cell proliferation and an increased tumor uptake [126]. The same group also fused this IL-2 variant to a PD-1-targeting antibody to directly deliver IL-2 to effector cells. The administration of the anti-PD-1 IL-2 variant eradicated pancreatic tumors in orthotopic models, while the co-administration of anti-PD-1 and an irrelevant IL-2 variant immunocytokine did not [127]. Another IL-2 variant with decreased binding to high affinity IL-2R $\alpha$ but increased binding to intermediate affinity IL-2R $\beta$ showed the augmentation of intratumoral CD8/Treg ratio and efficacy in melanoma and colon carcinoma models [128].

Variations have been developed without mutating the IL-2 sequence itself. One such variation includes the linkage of the chemotherapeutic drug DM1. This drug-conjugated immunocytokine retained IL-2 signaling in T cells and tumor-homing capabilities, but it exhibited a significant increase in tumor control with no elevation of toxicity [129]. An alternative structure design of cytokine conjugation to the light chain instead of the heavy chain of a full length antibody increased the half-life and therapeutic effect through the hinderance of the IL-2R $\beta$-binding portion of IL-2 [130]. Without specifically targeting a TAA, one group developed an IL-2/anti-IL-2 antibody complex that blocked IL-2 association with IL-2R $\alpha$. This antibody complex increased the cytokine's half-life in circulation, preferentially expanded CD8 ${ }^{+} \mathrm{T}$ cells over Tregs, and augmented the anti-tumor response [131,132]. Similarly, the specific PEGylation of unmutated IL-2 diminished IL-2R $\alpha$ binding and biased the molecule towards IL-2R $\beta$. This PEGylated IL-2 exhibited greater tumor retention and circulation half-life, increased infiltrating $\mathrm{CD} 8^{+} \mathrm{T}$ cells, and had superior tumor growth inhibition compared to unconjugated IL-2 in multiple murine models $[133,134]$. Tumor 
inhibition was significantly increased when co-administered with checkpoint inhibitors anti-CTLA-4 or anti-PD-1 $[133,135]$. This selective IL-2 variant has since progressed to phase II and III clinical trials in combination with anti-PD-1 (nivolumab) for advanced solid tumors, demonstrating a 50\% overall response rate in PD-L1 ${ }^{+}$tumors [136-139].

In an attempt to increase the safety profile of IFN- $\alpha$, a mutant was developed with a greater dissociation rate from its receptor, and it resulted in enhanced tumor-specific lysis while sparing healthy cells compared to the wild type [140,141]. This design led to tumor accumulation and efficacy in lymphoma, multiple myeloma, and melanoma models comparable to untargeted and wild-type IFN- $\alpha$ immunocytokines, though with significantly less toxicity $[141,142]$. A similar concept incorporated a mutated TNF or IFN- $\gamma$ with decreased affinity for its receptor and showed target-specific cytotoxicity, induced cellular adhesion molecules in the tumor, and did not increase toxicity [143]. A TNF mutant with a reduced potency was generated for an IL-2-TNF dual immunocytokine and controlled tumor progression when targeted to EDA in colon carcinoma, LLC, sarcoma, and teratocarcinoma models [144]. A strategy to limit the off-tumor effects of IL-12 involved separate constructs encoding the p35 and p40 subunits targeting EDA for dimerization/activation in the tumor microenvironment. However, this study suggested that the p35 subunit immunocytokine retained IL-12 signaling capabilities in T cells and NK cells [145].

\section{Immunocytokines in Combination Therapeutic Approaches}

Combinatorial regimens with immunocytokines have suggested additive or synergistic effects in pre-clinical tumor models compared to monotherapies. These investigated combinations include immunocytokines with chemotherapy agents, radiotherapy, monoclonal antibodies, cytokines, small molecule inhibitors, and vaccines.

\subsection{Chemotherapy}

As chemotherapy is the gold standard treatment for most advanced malignancies, the addition of immunocytokines have been explored in order to increase the efficacy of already established therapies. An early study indicated a significantly enhanced tumor growth control when administered in conjunction with paclitaxel or cyclophosphamide, at inefficacious dosages alone, in syngeneic breast, colon, and lung carcinoma models [146]. Similar results were seen in the context of targeting the tumor microenvironment with IL-2-based immunocytokines. In a xenograft model of melanoma, the EDA-specific immunocytokine abolished tumors when injected 4 or $24 \mathrm{~h}$ after paclitaxel. A look into the mechanism showed an increased vascular perfusion, immunocytokine tumor-homing, and NK cells in the tumor of combination-treated mice [147]. In a syngeneic melanoma model, the same EDA-targeting IL-2 immunocytokine increased the efficacy of both paclitaxel and dacarbazine [148]. Utilizing an IL-2 immunocytokine-targeting Tnc A1 augmented the control of tumor progression for both paclitaxel and doxorubicin in breast cancer-bearing mice without additional toxicity [149]. Targeting IL-2 to Tnc A1 in combination with temozolomide exhibited an increase in the arrest of tumor progression in subcutaneous and intracranial glioblastoma models compared to monotherapy. The combination significantly increased tumoral apoptosis and the infiltration of NK cells and macrophages [150].

Tumor necrosis factor-based immunocytokines have also shown an augmented therapeutic effect when combined with different chemotherapeutic drugs. A combination of HER2-targeted TNF with 5-fluorouracil (5-FU) significantly inhibited the growth of pancreatic cancer cells compared to monotherapy of either agent. This combination downregulated anti-apoptotic molecule Bcl-2 and signaling through the survival Akt pathway while upregulating the TNF receptor [151]. Targeting a trimeric TNF to EDA led to cures in two different sarcoma models when given in conjunction with doxorubicin at a concentration insufficient to cause tumor regression alone [152]. A TNF immunocytokine specific for EDB reiterated these results by increasing the cure rate for dacarbazine and trabectedin in a syngeneic sarcoma model with a temporary acute loss of body weight [153]. Other studies 
have demonstrated the increased anti-tumor efficacy of combination chemotherapy and IL-12, IL-7, IFN- $\gamma$, and IFN- $\alpha$ immunocytokines $[73,96,123,142,154]$.

\subsection{Radiotherapy}

Radiotherapy is used for the treatment of cancer because of its localized cytotoxicity and evident stimulation of an anti-cancer immune response [155]. Because of its immunostimulatory nature as well, the effects of IL-2 immunocytokines combined with radiation therapy have been documented. External beam radiation alone delayed tumor progression, but in combination with the intratumoral delivery of a GD2-targeting IL2 immunocytokine, there was significant tumor regression and survival in melanoma models. This reaction was dependent on ADCC and T cell infiltration, and it conferred protection against rechallenge. Even greater anti-tumor responses were seen when radiation, immunocytokine, and anti-CTLA- 4 blockade were combined in immunocytokine antigen-positive tumors $[156,157]$. However, the presence of a secondary untreated tumor negatively impacted the immunocytokine/radiation efficacy in primary treated pancreatic and melanoma tumors. This therapeutic inhibition was negated upon Treg depletion, anti-CTLA-4 addition, or the irradiation of all tumors [158]. In contrast, anti-EDB-IL-2 with radiation in colon cancer models caused a systemic anti-tumor response with control of tumor progression seen in secondary non-irradiated tumors in the combination group. This combination increased $\mathrm{CD} 8^{+} \mathrm{T}$ cells with a memory-like phenotype and protected against tumor rechallenge [159]. Radiotherapy given prior to anti-EDB-IL-2 significantly inhibited tumor progression in teratocarcinoma compared to monotherapy, with higher levels of infiltrating NK cells, and showed antigen density-dependency in colon, breast, and Lewis lung carcinoma $[160,161]$. A classified 'cold' neuroblastoma tumor achieved complete tumor eradication upon immune stimulation with anti-CTLA-4, anti-CD40, and toll-like receptor 9 (TLR9) agonist in addition to radiation and anti-GD2-IL-2 [162]. Additional studies have shown increased tumor control in vivo with combinations of radiotherapy and IL-2 immunocytokines targeting CEA and EpCAM [163-165].

Targeting IL-12 to the tumor in conjunction with radiation has indicated an increased benefit. Additive therapeutic efficacy was observed with the combination of radiation and a DNA-targeting IL-12 immunocytokine compared to monotherapies in syngeneic LLC models, along with enhanced tumor localization, after radiation was administered in xenograft rhabdomyosarcoma models $[96,166]$. Mice treated with radiation and DNAtargeting IL-12 showed a decreased tumor burden for both irradiated and non-irradiated tumors. This was accompanied by an increase in effector cells and a shift in the tumor microenvironment to a more pro-inflammatory cytokine milieu [167].

\subsection{Monoclonal Antibodies}

Monoclonal antibodies are the immunotherapeutic class with the greatest number of FDA approvals to date. The anti-CD20 monoclonal antibody rituximab was developed by IDEC pharmaceuticals and became the first FDA-approved cancer therapeutic monoclonal antibody [168]. This was followed by a cascade of FDA approvals for therapeutic antibody treatment in multiple blood cancers and solid tumors. A combination of rituximab and EDBspecific IL-2 immunocytokine eradicated tumors in multiple lymphoma xenografts with no apparent toxicity, while rituximab combined with IL-2 only delayed progression $[169,170]$. Immunocytokine alone, and to a greater extent with rituximab, increased macrophage and NK cell presence in the tumor compared to controls [170]. An antibody targeting syndecan-1 inhibited vascular tubule formation, and when co-administered with this EDB-targeting immunocytokine, melanoma tumors were ablated in $~ 71 \%$ of mice and a significant reduction occurred in ovarian tumor progression [171,172]. Targeted TNF to the melanoma antigen gp75 in combination with a monoclonal antibody of the same specificity augmented the efficacy in syngeneic melanoma models compared to either therapy alone. There was a loss of no more than $10 \%$ body weight in groups treated with immunocytokines [173]. 
While initial antibody development was targeted against tumor-associated molecules, there was a paradigm shift towards the development of antibodies that instead disrupted natural immune checkpoints that would otherwise suppress immune responses. The application of checkpoint inhibitors (CPIs) has led to the largest class of approved antibodies to date with the most indications in advanced solid tumors. Thus far, monoclonal antibody therapies targeting the immune checkpoints CTLA-4, PD-1, and PD-L1 have become commercially available, and so combinations with various immunocytokines have been investigated to enhance anti-cancer potential. Checkpoint inhibitors antagonistic for PD-L1 have exhibited increased survival and tumor control when combined with a decreased affinity IL-2-variant immunocytokine that targets CEA. The immunocytokine also enhanced the therapeutic efficacy of anti-HER2 and anti-EGFR [126]. A similar IL-2 mutant immunocytokine targeting EGFR had a synergistic effect with anti-PD-L1 in melanoma models [128]. In the context of a DNA-specific IL-12 immunocytokine, combination with anti-PD-L1 delayed colon, orthotopic bladder, and breast carcinoma progression with protection against rechallenge $[174,175]$. The immunocytokine with anti-PD-L1 had higher circulating levels of inflammatory cytokines, effector memory T cells, and intratumoral macrophages with high MHC expression compared with anti-PD-L1 alone [175]. Approximately $80 \%$ of tumor eradication was seen in colon cancer and sarcoma models when anti-PD-L1 was co-administered with IL-2 or TNF and IL-2 immunocytokines targeted to EDA and EDB [144,153]. The CPI anti-CTLA-4 has been studied with immunocytokine therapy and an anti-GD2-IL-2 immunocytokine increased the efficacy of CTLA-4 CPI in melanoma models in a T cell-dependent manner. Established tumor regression occurred with the further addition of innate immune cell activators anti-CD40 and TLR9 agonist [176]. Anti-CTLA-4 combined with EDB-targeted IL-2 caused teratocarcinoma and colon tumor regression to a greater extent when the immunocytokine was injected first [177].

\subsection{Other Combinations}

Immunocytokine therapy has had successful results upon incorporation into other established therapies. Various immunocytokines have been combined with additional unconjugated cytokines such as IL-7, IL-2, Fms-like tyrosine kinase-3-ligand (Flt3-L), and IFN- $\gamma$ to show enhanced tumor control and the activation of the immune response [85,178-180]. Of course, to increase the specificity and thus safety of cytokine addition, immunocytokines have been investigated in varying combinations with each other, including targeted TNF, IL-8, IFN- $\gamma$, IL-2, and IL-4 [73,74,95,148,177,181,182]. Immunocytokines have shown successful potentiation with other therapies such as small molecule inhibitors, vaccines, oncolytic viruses, resveratrol, and adoptive cell therapy [96,128,183-194].

\section{Clinical Investigations of Immunocytokines}

Based on the pre-clinical evidence, many immunocytokines have progressed to phase I/II clinical trials for different indications (Table 1). One of the first immunocytokines to make it to clinical trials delivered IL-2 to the GD2 antigen commonly found in melanoma and neuroblastoma tumors. A pilot study in melanoma patients showed dose-limiting toxicities of hypoxia, thrombocytopenia, hypotension, and hyperglycemia in 7/33 patients, all of which were reversible [195]. A phase I trial of this immunocytokine in pediatric neuroblastoma and one melanoma patient indicated tolerability with $8 / 28$ dose-limiting toxicities including neutropenia, leukopenia, hematuria, hypotension, thrombocytopenia, blurred vision, allergic reaction, and rash. Immune stimulation was observed with soluble circulating IL-2R and peaked at day four of treatment [196]. The further analysis of immune activation in metastatic melanoma patients showed increased $\mathrm{T}$ cell infiltrates in the tumor after treatment and a decrease in the targeted antigen GD2 [197]. Phase II trials in metastatic melanoma and neuroblastoma patients yielded 1/14 partial responses and $5 / 23$ complete responses, respectively [198,199]. To optimize the therapy in melanoma, a recent pilot trial in advanced resectable melanoma patients with a lower tumor burden resulted in a median recurrence-free survival (RFS) of 5.73 months but $6 / 18$ RFS cases 
at $\sim 57$ months [200]. The optimization of this immunocytokine in neuroblastoma led to a phase II trial in combination with GM-CSF and the vitamin A derivative isotretinoin. Five out of 45 patients had objective responses, and three of those had no events for up to five years. Four patients had dose-limiting toxicities [201]. The evaluation of the immune response to therapy showed that 32/61 patients developed anti-immunocytokine idiotype antibodies, which were not correlated with toxicity, and responses in neuroblastoma were associated with killer immunoglobulin-like receptor (KIR)/KIR ligand mismatch in NK cell activity [202,203]. In the context of resected advanced melanoma, patients treated with immunocytokine before resection showed a correlation between RFS/overall survival and inflammatory immune cell infiltration [204].

Table 1. Published clinical trials utilizing immunocytokines.

\begin{tabular}{|c|c|c|c|c|c|}
\hline Target Antigen & Disease & $\begin{array}{l}\text { Cytokine } \\
\text { Delivered }\end{array}$ & Phase & Clinical Trial \# & Reference \\
\hline GD2 & $\begin{array}{c}\text { Neuroblastoma } \\
\text { Melanoma } \\
\text { Sarcoma } \\
\text { Solid childhood tumors }\end{array}$ & IL-2 & I and II & $\begin{array}{l}\text { NCT00590824 } \\
\text { NCT00082758 } \\
\text { NCT03958383 } \\
\text { NCT03209869 } \\
\text { NCT01334515 } \\
\text { NCT00003750 } \\
\text { NCT00109863 }\end{array}$ & [195-205] \\
\hline Tnc A1 & $\begin{array}{c}\text { Breast carcinoma } \\
\text { AML } \\
\text { Solid tumors } \\
\text { MCC }\end{array}$ & IL-2 & I and II & $\begin{array}{l}\text { NCT01131364 } \\
\text { NCT01134250 } \\
\text { NCT02957032 } \\
\text { NCT02054884 } \\
\text { NCT03207191 }\end{array}$ & [206-209] \\
\hline EpCAM & $\begin{array}{c}\text { SCLC } \\
\text { Prostate carcinoma } \\
\text { Ovarian carcinoma } \\
\text { Breast carcinoma } \\
\text { Bladder carcinoma } \\
\text { Kidney carcinoma } \\
\text { Lung carcinoma } \\
\text { Solid tumors }\end{array}$ & IL-2 & I and II & $\begin{array}{l}\text { NCT00132522 } \\
\text { NCT00016237 }\end{array}$ & [210-212] \\
\hline EDB & $\begin{array}{c}\text { Melanoma } \\
\text { RCC } \\
\text { NSCLC } \\
\text { Solid tumors } \\
\text { Pancreatic carcinoma } \\
\text { Colorectal carcinoma } \\
\text { DLBCL } \\
\text { Glioblastoma } \\
\text { Sarcoma } \\
\text { Glioma }\end{array}$ & $\begin{array}{l}\text { IL-2 } \\
\text { IL-12 } \\
\text { TNF }\end{array}$ & I, II, and III & $\begin{array}{l}\text { NCT01058538 } \\
\text { NCT02086721 } \\
\text { NCT01198522 } \\
\text { NCT01253837 } \\
\text { NCT02076620 } \\
\text { NCT02076646 } \\
\text { NCT04471987 } \\
\text { NCT02957019 } \\
\text { NCT01213732 } \\
\text { NCT01055522 } \\
\text { NCT04443010 } \\
\text { NCT04032964 } \\
\text { NCT03420014 } \\
\text { NCT03779230 } \\
\text { NCT04573192 } \\
\text { NCT03705403 } \\
\text { NCT02938299 } \\
\text { NCT03567889 } \\
\text { NCT01253096 } \\
\text { NCT00625768 } \\
\text { NCT02076633 }\end{array}$ & {$[159,213-222]$} \\
\hline
\end{tabular}


Table 1. Cont

\begin{tabular}{|c|c|c|c|c|c|}
\hline Target Antigen & Disease & $\begin{array}{l}\text { Cytokine } \\
\text { Delivered }\end{array}$ & Phase & Clinical Trial \# & Reference \\
\hline $\begin{array}{l}\text { Histone/DNA } \\
\text { structures }\end{array}$ & $\begin{array}{c}\text { NSCLC } \\
\text { Solid tumors } \\
\text { Pancreatic carcinoma } \\
\text { Urogenital carcinoma } \\
\text { Bladder carcinoma } \\
\text { NHL } \\
\text { Kaposi sarcoma } \\
\text { Melanoma }\end{array}$ & $\begin{array}{l}\text { IL-2LT } \\
\text { IL-12 }\end{array}$ & I and II & $\begin{array}{l}\text { NCT04327986 } \\
\text { NCT04235777 } \\
\text { NCT00879866 } \\
\text { NCT01032681 } \\
\text { NCT04303117 } \\
\text { NCT01973608 } \\
\text { NCT01417546 } \\
\text { NCT02994953 }\end{array}$ & [223-227] \\
\hline CEA & Solid tumors & IL-2v & I & $\begin{array}{l}\text { NCT02350673 } \\
\text { NCT02004106 }\end{array}$ & {$[228,229]$} \\
\hline CD20 & B cell lymphoma & IL-2 & I and II & $\begin{array}{l}\text { NCT02151903 } \\
\text { NCT01874288 } \\
\text { NCT00720135 }\end{array}$ & [230-232] \\
\hline FAP & $\begin{array}{c}\text { Solid tumors } \\
\text { RCC } \\
\text { Melanoma } \\
\text { Pancreatic adenocarcinoma } \\
\text { Breast carcinoma } \\
\text { HNC } \\
\text { Esophageal carcinoma } \\
\text { Cervical carcinoma }\end{array}$ & IL-2v & I and II & $\begin{array}{l}\text { NCT03063762 } \\
\text { NCT03875079 } \\
\text { NCT03193190 } \\
\text { NCT02627274 } \\
\text { NCT03386721 }\end{array}$ & [233] \\
\hline PD-1 & Solid tumors & IL-2v & I & NCT04303858 & \\
\hline
\end{tabular}

Targets, diseases, delivered cytokines, trial phases, and references that describe clinical trials involving immunocytokines are listed. Antigen targets include GD2: disialoganglioside; Tnc A1: tenascin C A1 domain; EpCAM: epithelial cell adhesion molecule; EDB: fibronectin extra domain B; CEA: carcinoembryonic antigen; and FAP: fibroblast activation protein. Indication abbreviations are as follows. AML: acute myeloid leukemia; MCC: Merkel cell carcinoma; SCLC: squamous cell lung carcinoma; RCC: renal cell carcinoma; NSCLC: non-squamous cell lung carcinoma; DLBCL: diffuse large B cell lymphoma; NHL: non-Hodgkin's lymphoma; and HNC: head and neck cancer.

EDB-specific immunocytokines with payloads of TNF, IL-2, or IL-12 have been studied in phase I and II clinical trials. A first-in-man trial delivering TNF to solid tumors had only grade $1-2$ adverse events, except one patient with grade 3 bone pain at a site of metastasis, and stable disease in 19/31 participants [213]. A more localized approach evaluated the intratumoral administration of the IL-2 EDB-targeting immunocytokine in 24 stage III melanoma patients and was well-tolerated, with complete responses seen in $44 \%$ of treated lesions and $45 \%$ of non-treated lesions. A significant increase was seen in circulating $\mathrm{CD}^{+} \mathrm{T}$ cells, $\mathrm{CD}^{+} \mathrm{T}$ cells, NK cells, and Tregs, and a decrease was seen in circulating MDSCs [214]. A phase II trial incorporating anti-EDB IL-2 and TNF immunocytokines in 20 stage III and IV melanoma patients resulted in $30 \%$ of lesions experiencing a complete response. There was increased necrosis in biopsies from the treated lesions and a significant infiltration of $\mathrm{CD} 8^{+} \mathrm{T}$ cells [215]. This combination of EDB-targeting immunocytokines has since progressed to phase III trials for intratumoral delivery to melanoma patients prior to resection (NCT02938299 and NCT03567889). A phase I study for the combination of the IL-2 immunocytokine and the chemotherapeutic agent dacarbazine in metastatic melanoma exhibited low rates of severe toxicity, mainly grade 4 leukopenia/neutropenia and grade 3 hypotension. Of the 29 patients, $28 \%$ had an objective response to the therapy [216]. This combination progressed to a phase II trial in which $7 / 38$ patients receiving both therapies experienced an objective response compared to $1 / 22$ patients receiving only dacarbazine. The mean progression-free survival (PFS) for the two differentially scheduled combination treatment groups was 99 days and 74 days compared to 59 days for the control group, although this was not statistically significant. Four cases of grade 4 neutropenia and one case of grade 4 thrombocytopenia were reported in the combination groups [217]. Further targeting IL-2 to EDB in solid tumors and RCC in a phase I/II study indicated 
tolerable toxicity with no grade 4 events and most of the grade 3 events occurring at the higher dose. Seventeen out of 33 patients presented with stable disease, and the mean PFS in the phase II arm was eight months, with two patients surpassing 24 months [218]. An immunocytokine utilizing a different EDB-specific antibody conjugated to IL-12 was trialed in melanoma and RCC patients and exhibited tolerability with transient grade 3 hematological toxicity, fatigue, fainting, dehydration, and urinary frequency events. The immunocytokine increased the circulating levels of IFN-g and CXCL10. Stable disease was experienced in 5/13 patients, with one partial response [219]. A comprehensive list of clinical trials involving immunocytokines for the treatment of cancer is detailed in Table 1.

\section{Summary}

Pre-clinical evidence is strong for targeted cytokine delivery through the immunocytokine format in different indications and has led to multiple clinical trials. Few immunocytokines have progressed to phase II trials, and only two (anti-EDB-IL-2 and anti-EDB-TNF) have progressed to a larger scale phase III. Continual investigation into the optimization of this immunotherapy with combinatorial agents could bring to light an encompassing understanding of its therapeutic value.

Funding: This research received no external funding.

Institutional Review Board Statement: Not applicable.

Informed Consent Statement: Not applicable.

Data Availability Statement: Not applicable.

Conflicts of Interest: The authors declare no conflict of interest.

\section{References}

1. Dunn, G.P.; Bruce, A.T.; Ikeda, H.; Old, L.J.; Schreiber, R.D. Cancer Immunoediting: From Immunosurveillance to Tumor Escape. Nat. Immunol. 2002, 3, 991-998. [CrossRef]

2. Dighe, A.S.; Richards, E.; Old, L.J.; Schreiber, R.D. Enhanced in Vivo Growth and Resistance to Rejection of Tumor Cells Expressing Dominant Negative IFN $\gamma$ Receptors. Immunity 1994, 1, 447-456. [CrossRef]

3. Mochizuki, D.Y.; Watson, J.; Gillis, S. Biochemical Separation of Interleukin 2. J. Immunol. Methods 1980, 39, 185-201. [CrossRef]

4. Morgan, D.A.; Ruscetti, F.W.; Gallo, R. Selective in Vitro Growth of T Lymphocytes from Normal Human Bone Marrows. Science 1976, 193, 1007-1008. [CrossRef]

5. Mills, G.B.; Carlson, G.; Paetkau, V. Generation of Cytotoxic Lymphocytes to Syngeneic Tumors by Using Co-Stimulator (Interleukin 2): In Vivo Activity. J. Immunol. 1980, 125, 1904-1909. [PubMed]

6. Cheever, M.A.; Greenberg, P.D.; Fefer, A.; Gillis, S. Augmentation of the Anti-Tumor Therapeutic Efficacy of Long-Term Cultured T Lymphocytes by in Vivo Administration of Purified Interleukin 2. J. Exp. Med. 1982, 155, 968-980. [CrossRef] [PubMed]

7. Lienard, D.; Ewalenko, P.; Delmotte, J.J.; Renard, N.; Lejeune, F.J. High-Dose Recombinant Tumor Necrosis Factor Alpha in Combination with Interferon Gamma and Melphalan in Isolation Perfusion of the Limbs for Melanoma and Sarcoma. J. Clin. Oncol. 1992, 10, 52-60. [CrossRef] [PubMed]

8. Eggermont, A.M.M.; Koops, H.S.; Klausner, J.M.; Kroon, B.B.R.; Schlag, P.M.; Liénard, D.; Van Geel, A.N.; Hoekstra, H.J.; Meller, I.; Nieweg, O.E.; et al. Isolated Limb Perfusion with Tumor Necrosis Factor and Melphalan for Limb Salvage in 186 Patients with Locally Advanced Soft Tissue Extremity Sarcomas: The Cumulative Multicenter European Experience. Ann. Surg. 1996, 224, 756-765. [CrossRef] [PubMed]

9. Berraondo, P.; Sanmamed, M.F.; Ochoa, M.C.; Etxeberria, I.; Aznar, M.A.; Pérez-Gracia, J.L.; Rodríguez-Ruiz, M.E.; Ponz-Sarvise, M.; Castañón, E.; Melero, I. Cytokines in Clinical Cancer Immunotherapy. Br. J. Cancer 2019, 120, 6-15. [CrossRef] [PubMed]

10. Golomb, H.M.; Jacobs, A.; Fefer, A.; Ozer, H.; Thompson, J.; Portlock, C.; Ratain, M.; Golde, D.; Vardiman, J.; Burke, J.S. Alpha-2 Interferon Therapy of Hairy-Cell Leukemia: A Multicenter Study of 64 Patients. J. Clin. Oncol. 1986, 4, 900-905. [CrossRef]

11. Groopman, J.E.; Gottlieb, M.S.; Goodman, J.; Mitsuyasu, R.T.; Conant, M.A.; Prince, H.; Fahey, J.L.; Derezin, M.; Weinstein, W.M.; Casavante, C. Recombinant Alpha-2 Interferon Therapy for Kaposi's Sarcoma Associated with the Acquired Immunodeficiency Syndrome. Ann. Intern. Med. 1984, 100, 671-676. [CrossRef]

12. Volberding, P.A.; Mitsuyasu, R.T.; Golando, J.P.; Spiegel, R.J. Treatment of Kaposi's Sarcoma with Interferon Alfa-2b (Intron A). Cancer 1987, 59, 620-625. [CrossRef]

13. Kirkwood, J.M.; Strawderman, M.H.; Ernstoff, M.S.; Smith, T.J.; Borden, E.C.; Blum, R.H. Interferon Alfa-2b Adjuvant Therapy of High-Risk Resected Cutaneous Melanoma: The Eastern Cooperative Oncology Group Trial EST 1684. J. Clin. Oncol. 1996, 14, 7-17. [CrossRef] [PubMed] 
14. Solal-Celigny, P.; Lepage, E.; Brousse, N.; Reyes, F.; Haioun, C.; Leporrier, M.; Peuchmaur, M.; Bosly, A.; Parlier, Y.; Brice, P.; et al. Recombinant Interferon Alfa-2b Combined with a Regimen Containing Doxorubicin in Patients with Advanced Follicular Lymphoma. N. Engl. J. Med. 1993, 329, 1608-1614. [CrossRef] [PubMed]

15. Fyfe, G.; Fisher, R.I.; Rosenberg, S.A.; Sznol, M.; Parkinson, D.R.; Louie, A.C. Results of Treatment of 255 Patients with Metastatic Renal Cell Carcinoma Who Received High-Dose Recombinant Interleukin-2 Therapy. J. Clin. Oncol. 1995, 13, 688-696. [CrossRef]

16. Atkins, M.B.; Lotze, M.T.; Dutcher, J.P.; Fisher, R.I.; Weiss, G.; Margolin, K.; Abrams, J.; Sznol, M.; Parkinson, D.; Hawkins, M.; et al. High-Dose Recombinant Interleukin 2 Therapy for Patients with Metastatic Melanoma: Analysis of 270 Patients Treated between 1985 and 1993. J. Clin. Oncol. 1999, 17, 2105-2116. [CrossRef]

17. Rosenberg, S.A.; Lotze, M.T.; Yang, J.C.; Topalian, S.L.; Chang, A.E.; Schwartzentruber, D.J.; Aebersold, P.; Leitman, S.; Linehan, W.M.; Seipp, C.A.; et al. Prospective Randomized Trial of High-Dose Interleukin-2 Alone or in Conjunction With LymphokineActivated Killer Cells for the Treatment of Patients With Advanced Cancer. JNCI 1993, 85, 622-632. [CrossRef]

18. Köhler, G.; Milstein, C. Continuous Cultures of Fused Cells Secreting Antibody of Predefined Specificity. Nature 1975, 256, 495-497. [CrossRef]

19. Smith, G.P. Filamentous Fusion Phage: Novel Expression Vectors That Display Cloned Antigens on the Virion Surface. Science 1985, 228, 1315-1317. [CrossRef]

20. Clackson, T.; Hoogenboom, H.R.; Griffiths, A.D.; Winter, G. Making Antibody Fragments Using Phage Display Libraries. Nature 1991, 352, 624-628. [CrossRef]

21. Barbas, C.F.; Kang, A.S.; Lerner, R.A.; Benkovic, S.J. Assembly of Combinatorial Antibody Libraries on Phage Surfaces: The Gene III Site. Proc. Natl. Acad. Sci. USA 1991, 88, 7978-7982. [CrossRef]

22. Breitling, F.; Dübel, S.; Seehaus, T.; Klewinghaus, I.; Little, M. A Surface Expression Vector for Antibody Screening. Gene 1991, 104, 147-153. [CrossRef]

23. Carnemolla, B.; Borsi, L.; Balza, E.; Castellani, P.; Meazza, R.; Berndt, A.; Ferrini, S.; Kosmehl, H.; Neri, D.; Zardi, L. Enhancement of the Antitumor Properties of Interleukin-2 by Its Targeted Delivery to the Tumor Blood Vessel Extracellular Matrix. Blood 2002, 99, 1659-1665. [CrossRef]

24. Borsi, L.; Balza, E.; Carnemolla, B.; Sassi, F.; Castellani, P.; Berndt, A.; Kosmehl, H.; Birò, A.; Siri, A.; Orecchia, P.; et al. Selective Targeted Delivery of TNF $\alpha$ to Tumor Blood Vessels. Blood 2003, 102, 4384-4392. [CrossRef]

25. Hoogenboom, H.R.; Volckaert, G.; Raus, J.C.M. Construction and Expression of Antibody-Tumor Necrosis Factor Fusion Proteins. Mol. Immunol. 1991, 28, 1027-1037. [CrossRef]

26. Gillies, S.D.; Young, D.; Lo, K.M.; Foley, S.F.; Reisfeld, R.A. Expression of Genetically Engineered Immunoconjugates of Lymphotoxin and a Chimeric Anti-Ganglioside GD2 Antibody. Hybridoma 1991, 10, 347-356. [CrossRef]

27. Gillies, S.D.; Reilly, E.B.; Lo, K.M.; Reisfeld, R.A. Antibody-Targeted Interleukin 2 Stimulates T-Cell Killing of Autologous Tumor Cells. Proc. Natl. Acad. Sci. USA 1992, 89, 1428-1432. [CrossRef] [PubMed]

28. Fell, H.P.; Gayle, M.A.; Grosmaire, L.; Ledbetter, J.A. Genetic Construction and Characterization of a Fusion Protein Consisting of a Chimeric $\mathrm{F}\left(\mathrm{Ab}^{\prime}\right)$ with Specificity for Carcinomas and Human IL-2. J. Immunol. 1991, 146, 2446-2452. [PubMed]

29. Savage, P.; So, A.; Spooner, R.A.; Epenetos, A.A. A Recombinant Single Chain Antibody Interleukin-2 Fusion Protein. Br. J. Cancer 1993, 67, 304-310. [CrossRef]

30. Sabzevari, H.; Gillies, S.D.; Mueller, B.M.; Pancook, J.D.; Reisfeld, R.A. A Recombinant Antibody-Interleukin 2 Fusion Protein Suppresses Growth of Hepatic Human Neuroblastoma Metastases in Severe Combined Immunodeficiency Mice. Proc. Natl. Acad. Sci. USA 1994, 91, 9626-9630. [CrossRef]

31. Gillies, S.D.; Lan, Y.; Williams, S.; Carr, F.; Forman, S.; Raubitschek, A.; Lo, K.M. An Anti-CD20-IL-2 Immunocytokine Is Highly Efficacious in a SCID Mouse Model of Established Human B Lymphoma. Blood 2005, 105, 3972-3978. [CrossRef]

32. Keizer, R.J.; Huitema, A.D.R.; Schellens, J.H.M.; Beijnen, J.H. Clinical Pharmacokinetics of Therapeutic Monoclonal Antibodies. Clin. Pharmacokinet. 2010, 49, 493-507. [CrossRef]

33. Borsi, L.; Balza, E.; Bestagno, M.; Castellani, P.; Carnemolla, B.; Biro, A.; Leprini, A.; Sepulveda, J.; Burrone, O.; Neri, D.; et al. Selective Targeting of Tumoral Vasculature: Comparison of Different Formats of an Antibody (L19) to the ED-B Domain of Fibronectin. Int. J. Cancer 2002, 102, 75-85. [CrossRef]

34. Gafner, V.; Trachsel, E.; Neri, D. An Engineered Antibody-Interleukin-12 Fusion Protein with Enhanced Tumor Vascular Targeting Properties. Int. J. Cancer 2006, 119, 2205-2212. [CrossRef]

35. Malek, T.R. The Biology of Interleukin-2. Annu. Rev. Immunol. 2008, 26, 453-479. [CrossRef] [PubMed]

36. Becker, J.C.; Varki, N.; Gillies, S.D.; Furukawa, K.; Reisfeld, R.A. Long-Lived and Transferable Tumor Immunity in Mice after Targeted Interleukin-2 Therapy. J. Clin. Investig. 1996, 98, 2801-2804. [CrossRef] [PubMed]

37. Becker, J.C.; Pancook, J.D.; Gillies, S.D.; Mendelsohn, J.; Reisfeld, R.A. Eradication of Human Hepatic and Pulmonary Melanoma Metastases in SCID Mice by Antibody-Interleukin 2 Fusion Proteins. Proc. Natl. Acad. Sci. USA 1996, 93, 2702-2707. [CrossRef]

38. Becker, J.C.; Pancook, J.D.; Gillies, S.D.; Furukawa, K.; Reisfeld, R.A. T Cell-Mediated Eradication of Murine Metastatic Melanoma Induced by Targeted Interleukin 2 Therapy. J. Exp. Med. 1996, 183, 2361-2366. [CrossRef] [PubMed]

39. Becker, J.C.; Varki, N.; Gillies, S.D.; Furukawa, K.; Reisfeld, R.A. An Antibody-Interleukin 2 Fusion Protein Overcomes Tumor Heterogeneity by Induction of a Cellular Immune Response. Proc. Natl. Acad. Sci. USA 1996, 93, 7826-7831. [CrossRef] [PubMed]

40. Lode, H.N.; Xiang, R.; Varki, N.M.; Dolman, C.S.; Gillies, S.D.; Reisfeld, R.A. Targeted Interleukin-2 Therapy for Spontaneous Neuroblastoma Metastases to Bone Marrow. J. Natl. Cancer Inst. 1997, 89, 1586-1594. [CrossRef] 
41. Lode, H.N.; Xiang, R.; Pertl, U.; Förster, E.; Schoenberger, S.P.; Gillies, S.D.; Reisfeld, R.A. Melanoma Immunotherapy by Targeted IL-2 Depends on CD4+ T-Cell Help Mediated by CD40/CD40L Interaction. J. Clin. Investig. 2000, 105, 1623-1630. [CrossRef]

42. Lode, H.N.; Xiang, R.; Dreier, T.; Varki, N.M.; Gillies, S.D.; Reisfeld, R.A. Natural Killer Cell-Mediated Eradication of Neuroblastoma Metastases to Bone Marrow by Targeted Interleukin-2 Therapy. Blood 1998, 91, 1706-1715. [CrossRef] [PubMed]

43. Mannino, M.H.; Zhu, Z.; Xiao, H.; Bai, Q.; Wakefield, M.R.; Fang, Y. The Paradoxical Role of IL-10 in Immunity and Cancer. Cancer Lett. 2015, 367, 103-107. [CrossRef]

44. Yang, R.K.; Kalogriopoulos, N.A.; Rakhmilevich, A.L.; Ranheim, E.A.; Seo, S.; Kim, K.; Alderson, K.L.; Gan, J.; Reisfeld, R.A.; Gillies, S.D.; et al. Intratumoral Hu14.18-IL-2 (IC) Induces Local and Systemic Antitumor Effects That Involve Both Activated T and NK Cells As Well As Enhanced IC Retention. J. Immunol. 2012, 189, 2656-2664. [CrossRef]

45. Yang, R.K.; Kalogriopoulos, N.A.; Rakhmilevich, A.L.; Ranheim, E.A.; Seo, S.; Kim, K.; Alderson, K.L.; Gan, J.; Reisfeld, R.A.; Gillies, S.D.; et al. Intratumoral Treatment of Smaller Mouse Neuroblastoma Tumors with a Recombinant Protein Consisting of IL-2 Linked to the Hu14.18 Antibody Increases Intratumoral CD8+ T and NK Cells and Improves Survival. Cancer Immunol. Immunother. 2013, 62, 1303-1313. [CrossRef] [PubMed]

46. Buhtoiarov, I.N.; Neal, Z.C.; Gan, J.; Buhtoiarova, T.N.; Patankar, M.S.; Gubbels, J.A.A.; Hank, J.A.; Yamane, B.; Rakhmilevich, A.L.; Reisfeld, R.A.; et al. Differential Internalization of Hu14.18-IL2 Immunocytokine by NK and Tumor Cell: Impact on Conjugation, Cytotoxicity, and Targeting. J. Leukoc. Biol. 2011, 89, 625-638. [CrossRef] [PubMed]

47. Johnson, E.E.; Lum, H.D.; Rakhmilevich, A.L.; Schmidt, B.E.; Furlong, M.; Buhtoiarov, I.N.; Hank, J.A.; Raubitschek, A.; Colcher, D.; Reisfeld, R.A.; et al. Intratumoral Immunocytokine Treatment Results in Enhanced Antitumor Effects. Cancer Immunol. Immunother. 2008, 57, 1891-1902. [CrossRef]

48. Gubbels, J.A.A.; Gadbaw, B.; Buhtoiarov, I.N.; Horibata, S.; Kapur, A.K.; Patel, D.; Hank, J.A.; Gillies, S.D.; Sondel, P.M.; Patankar, M.S.; et al. Ab-IL2 Fusion Proteins Mediate NK Cell Immune Synapse Formation by Polarizing CD25 to the Target Cell-Effector Cell Interface. Cancer Immunol. Immunother. 2011, 60, 1789-1800. [CrossRef]

49. Rybak, J.N.; Roesli, C.; Kaspar, M.; Villa, A.; Neri, D. The Extra-Domain A of Fibronectin Is a Vascular Marker of Solid Tumors and Metastases. Cancer Res. 2007, 67, 10948-10957. [CrossRef] [PubMed]

50. Zardi, L.; Carnemolla, B.; Siri, A.; Petersen, T.E.; Paolella, G.; Sebastio, G.; Baralle, F.E. Transformed Human Cells Produce a New Fibronectin Isoform by Preferential Alternative Splicing of a Previously Unobserved Exon. EMBO J. 1987, 6, $2337-2342$. [CrossRef] [PubMed]

51. Borsi, L.; Carnemolla, B.; Nicolò, G.; Spina, B.; Tanara, G.; Zardi, L. Expression of Different Tenascin Isoforms in Normal, Hyperplastic and Neoplastic Human Breast Tissues. Int. J. Cancer 1992, 52, 688-692. [CrossRef]

52. Brack, S.S.; Silacci, M.; Birchler, M.; Neri, D. Tumor-Targeting Properties of Novel Antibodies Specific to the Large Isoform of Tenascin-C. Clin. Cancer Res. 2006, 12, 3200-3208. [CrossRef]

53. Ziffels, B.; Pretto, F.; Neri, D. Intratumoral Administration of IL2-and TNF-Based Fusion Proteins Cures Cancer without Establishing Protective Immunity. Immunotherapy 2018, 10, 177-188. [CrossRef] [PubMed]

54. Gutbrodt, K.L.; Schliemann, C.; Giovannoni, L.; Frey, K.; Pabst, T.; Klapper, W.; Berdel, W.E.; Neri, D. Antibody-Based Delivery of Interleukin-2 to Neovasculature Has Potent Activity against Acute Myeloid Leukemia. Sci. Transl. Med. 2013, 5. [CrossRef] [PubMed]

55. Wieckowski, S.; Hemmerle, T.; Prince, S.S.; Schlienger, B.D.; Hillinger, S.; Neri, D.; Zippelius, A. Therapeutic Efficacy of the F8-IL2 Immunocytokine in a Metastatic Mouse Model of Lung Adenocarcinoma. Lung Cancer 2015, 88, 9-15. [CrossRef] [PubMed]

56. Sugimoto, Y.; Hirota, M.; Yoshikawa, K.; Sumitomo, M.; Nakamura, K.; Ueda, R.; Niwa, R.; Suzawa, T.; Yamasaki, M.; Shitara, K.; et al. The Therapeutic Potential of a Novel PSMA Antibody and Its IL-2 Conjugate in Prostate Cancer. Anticancer Res. 2014, 34, 89-97. [PubMed]

57. Hornick, J.L.; Khawli, L.A.; Hu, P.; Sharifi, J.; Khanna, C.; Epstein, A.L. Pretreatment with a Monoclonal Antibody/Interleukin-2 Fusion Protein Directed against DNA Enhances the Delivery of Therapeutic Molecules to Solid Tumors. Clin. Cancer Res. 1999, 5, 51-60.

58. Chen, X.; Xu, J.; Guo, Q.; Wang, L.; Yang, Y.; Guo, H.; Gu, N.; Zhang, D.; Qian, W.; Hou, S.; et al. Therapeutic Efficacy of an Anti-PD-L1 Antibody Based Immunocytokine in a Metastatic Mouse Model of Colorectal Cancer. Biochem. Biophys. Res. Commun. 2016, 480, 160-165. [CrossRef] [PubMed]

59. Ziffels, B.; Stringhini, M.; Probst, P.; Fugmann, T.; Sturm, T.; Neri, D. Antibody-Based Delivery of Cytokine Payloads to Carbonic Anhydrase IX Leads to Cancer Cures in Immunocompetent Tumor-Bearing Mice. Mol. Cancer Ther. 2019, 18, 1544-1554. [CrossRef]

60. Christ, O.; Seiter, S.; Matzku, S.; Burger, C.; Zöller, M. Efficacy of Local versus Systemic Application of Antibody-Cytokine Fusion Proteins in Tumor Therapy. Clin. Cancer Res. 2001, 7, 985-998.

61. Dougan, M.; Ingram, J.R.; Jeong, H.J.; Mosaheb, M.M.; Bruck, P.T.; Ali, L.; Pishesha, N.; Blomberg, O.; Tyler, P.M.; Servos, M.M.; et al. Targeting Cytokine Therapy to the Pancreatic Tumor Microenvironment Using PD-L1-Specific VHHs. Cancer Immunol. Res. 2018, 6, 389-401. [CrossRef] [PubMed]

62. Vilcek, J. Fifty Years of Interferon Research: Aiming at a Moving Target. Immunity 2006, 25, 343-348. [CrossRef] [PubMed]

63. Rossi, E.A.; Goldenberg, D.M.; Cardillo, T.M.; Stein, R.; Chang, C.H. CD20-Targeted Tetrameric Interferon- $\alpha$, a Novel and Potent Immunocytokine for the Therapy of B-Cell Lymphomas. Blood 2009, 114, 3864-3871. [CrossRef]

64. Rossi, E.A.; Rossi, D.L.; Cardillo, T.M.; Stein, R.; Goldenberg, D.M.; Chang, C.H. Preclinical Studies on Targeted Delivery of Multiple IFN $\alpha 2 b$ to HLA-DR in Diverse Hematologic Cancers. Blood 2011, 118, 1877-1884. [CrossRef] 
65. Rossi, E.A.; Rossi, D.L.; Stein, R.; Goldenberg, D.M.; Chang, C.H. A Bispecific Antibody-IFN $\alpha 2 b$ Immunocytokine Targeting CD20 and HLA-DR Is Highly Toxic to Human Lymphoma and Multiple Myeloma Cells. Cancer Res. 2010, 70, 7600-7609. [CrossRef] [PubMed]

66. Guo, J.; Xiao, Y.; Iyer, R.; Lu, X.; Lake, M.; Ladror, U.; Harlan, J.; Samanta, T.; Tomlinson, M.; Bukofzer, G.; et al. Empowering Therapeutic Antibodies with IFN- $\alpha$ for Cancer Immunotherapy. PLoS ONE 2019, 14, e219892. [CrossRef] [PubMed]

67. Xuan, C.; Steward, K.K.; Timmerman, J.M.; Morrison, S.L. Targeted Delivery of Interferon-Alpha via Fusion to Anti-CD20 Results in Potent Antitumor Activity against B-Cell Lymphoma. Blood 2010, 115, 2864-2871. [CrossRef]

68. Liang, Y.; Tang, H.; Guo, J.; Qiu, X.; Yang, Z.; Ren, Z.; Sun, Z.; Bian, Y.; Xu, L.; Xu, H.; et al. Targeting IFN $\alpha$ to Tumor by Anti-PD-L1 Creates Feedforward Antitumor Responses to Overcome Checkpoint Blockade Resistance. Nat. Commun. 2018, 9, 1-11. [CrossRef]

69. Frey, K.; Zivanovic, A.; Schwager, K.; Neri, D. Antibody-Based Targeting of Interferon-Alpha to the Tumor Neovasculature: A Critical Evaluation. Integr. Biol. 2011, 3, 468-478. [CrossRef] [PubMed]

70. Farrar, M.A.; Schreiber, R.D. The Molecular Cell Biology of Interferon- $\gamma$ and Its Receptor. Annu. Rev. Immunol. 1993, 11, 571-611. [CrossRef]

71. Street, S.E.A.; Cretney, E.; Smyth, M.J. Perforin and Interferon- $\gamma$ Activities Independently Control Tumor Initiation, Growth, and Metastasis. Blood 2001, 97, 192-197. [CrossRef]

72. Street, S.E.A.; Trapani, J.A.; MacGregor, D.; Smyth, M.J. Suppression of Lymphoma and Epithelial Malignancies Effected by Interferon $\gamma$. J. Exp. Med. 2002, 196, 129-134. [CrossRef] [PubMed]

73. Ebbinghaus, C.; Ronca, R.; Kaspar, M.; Grabulovski, D.; Berndt, A.; Kosmehl, H.; Zardi, L.; Neri, D. Engineered Vascular-Targeting Antibody-Interferon- $\gamma$ Fusion Protein for Cancer Therapy. Int. J. Cancer 2005, 116, 304-313. [CrossRef]

74. Hemmerle, T.; Neri, D. The Dose-Dependent Tumor Targeting of Antibody-IFN $\gamma$ Fusion Proteins Reveals an Unexpected Receptor-Trapping Mechanism in Vivo. Cancer Immunol. Res. 2014, 2, 559-567. [CrossRef] [PubMed]

75. Liu, D.; Chang, C.H.; Rossi, E.A.; Cardillo, T.M.; Goldenberg, D.M. Interferon- $\Lambda 1$ Linked to a Stabilized Dimer of Fab Potently Enhances Both Antitumor and Antiviral Activities in Targeted Cells. PLoS ONE 2013, 8, e63940. [CrossRef]

76. Aggarwal, B.B.; Gupta, S.C.; Kim, J.H. Historical Perspectives on Tumor Necrosis Factor and Its Superfamily: 25 Years Later, a Golden Journey. Blood 2012, 119, 651-665. [CrossRef] [PubMed]

77. Aggarwal, B.B.; Schwarz, L.; Hogan, M.E.; Rando, R.F. Triple Helix-Forming Oligodeoxyribonucleotides Targeted to the Human Tumor Necrosis Factor (TNF) Gene Inhibit TNF Production and Block the TNF-Dependent Growth of Human Glioblastoma Tumor Cells. Cancer Res. 1996, 56, 5156-5164.

78. Giri, D.K.; Aggarwal, B.B. Constitutive Activation of NF-KB Causes Resistance to Apoptosis in Human Cutaneous T Cell Lymphoma HuT-78 Cells: Autocrine Role of Tumor Necrosis Factor and Reactive Oxygen Intermediates. J. Biol. Chem. 1998, 273, 14008-14014. [CrossRef]

79. Szlosarek, P.W.; Grimshaw, M.J.; Kulbe, H.; Wilson, J.L.; Wilbanks, G.D.; Burke, F.; Balkwill, F.R. Expression and Regulation of Tumor Necrosis Factor $\alpha$ in Normal and Malignant Ovarian Epithelium. Mol. Cancer Ther. 2006, 5, 382-390. [CrossRef] [PubMed]

80. Zins, K.; Abraham, D.; Sioud, M.; Aharinejad, S. Colon Cancer Cell-Derived Tumor Necrosis Factor- $\alpha$ Mediates the Tumor Growth-Promoting Response in Macrophages by up-Regulating the Colony-Stimulating Factor-1 Pathway. Cancer Res. 2007, 67, 1038-1045. [CrossRef]

81. Hoogenboom, H.R.; Raus, J.C.M.; Volckaert, G. Targeting of Tumor Necrosis Factor to Tumor Cells: Secretion by Myeloma Cells of a Genetically Engineered Antibody-Tumor Necrosis Factor Hybrid Molecule. BBA Mol. Basis Dis. 1991, 1096, 345-354. [CrossRef]

82. Gillies, S.D.; Young, D.; Lo, K.M.; Roberts, S. Biological Activity and in Vivo Clearance of Antitumor Antibody/Cytokine Fusion Proteins. Bioconjug. Chem. 1993, 4, 230-235. [CrossRef] [PubMed]

83. Bauer, S.; Adrian, N.; Williamson, B.; Panousis, C.; Fadle, N.; Smerd, J.; Fettah, I.; Scott, A.M.; Pfreundschuh, M.; Renner, C. Targeted Bioactivity of Membrane-Anchored TNF by an Antibody-Derived TNF Fusion Protein. J. Immunol. 2004, 172, 3930-3939. [CrossRef] [PubMed]

84. Halin, C.; Gafner, V.; Villani, M.E.; Borsi, L.; Berndt, A.; Kosmehl, H.; Zardi, L.; Neri, D. Synergistic Therapeutic Effects of a Tumor Targeting Antibody Fragment, Fused to Interleukin 12 and to Tumor Necrosis Factor $\alpha$. Cancer Res. 2003, 63, 3202.

85. Bauer, S.; Oosterwijk-Wakka, J.C.; Adrian, N.; Oosterwijk, E.; Fischer, E.; Wüest, T.; Stenner, F.; Perani, A.; Cohen, L.; Knuth, A.; et al. Targeted Therapy of Renal Cell Carcinoma: Synergistic Activity of CG250-TNF and IFNg. Int. J. Cancer 2009, 125, 115-123. [CrossRef] [PubMed]

86. Rosenblum, M.G.; Horn, S.A.; Cheung, L.H. A Novel Recombinant Fusion Toxin Targeting HER-2/NEU-over-Expressing Cells and Containing Human Tumor Necrosis Factor. Int. J. Cancer 2000, 88, 267-273. [CrossRef]

87. Lyu, M.A.; Rosenblum, M.G. The Immunocytokine ScFv23/TNF Sensitizes HER-2/Neu-Overexpressing SKBR-3 Cells to Tumor Necrosis Factor (TNF) via up-Regulation of TNF Receptor-1. Mol. Cancer Ther. 2005, 4, 1205-1213. [CrossRef]

88. Zundler, S.; Neurath, M.F. Interleukin-12: Functional Activities and Implications for Disease. Cytokine Growth Factor Rev. 2015, 26, 559-568. [CrossRef]

89. Atkins, M.B.; Robertson, M.J.; Gordon, M.; Lotze, M.T.; DeCoste, M.; DuBois, J.S.; Ritz, J.; Sandler, A.B.; Edington, H.D.; Garzone, P.D.; et al. Phase I Evaluation of Intravenous Recombinant Human Interleukin 12 in Patients with Advanced Malignancies. Clin. Cancer Res. 1997, 3, 409-417.

90. Halin, C.; Rondini, S.; Nilsson, F.; Berndt, A.; Kosmehl, H.; Zardi, L.; Neri, D. Enhancement of the Antitumor Activity of Interleukin-12 by Targeted Delivery to Neovasculature. Nat. Biotechnol. 2002, 20, 264-269. [CrossRef] 
91. Ongaro, T.; Matasci, M.; Cazzamalli, S.; Gouyou, B.; De Luca, R.; Neri, D.; Villa, A. A Novel Anti-Cancer L19-Interleukin-12 Fusion Protein with an Optimized Peptide Linker Efficiently Localizes in Vivo at the Site of Tumors. J. Biotechnol. 2019, $291,17-25$. [CrossRef]

92. Gillies, S.D.; Lo, K.M.; Lan, Y.; Dahl, T.; Wong, W.K.; Burger, C. Improved Circulating Half-Life and Efficacy of an AntibodyInterleukin 2 Immunocytokine Based on Reduced Intracellular Proteolysis. Clin. Cancer Res. 2002, 8, 210-216. [PubMed]

93. Lo, K.M.; Lan, Y.; Lauder, S.; Zhang, J.; Brunkhorst, B.; Qin, G.; Verma, R.; Courtenay-Luck, N.; Gillies, S.D. HuBC1-IL12, an Immunocytokine Which Targets EDB-Containing Oncofetal Fibronectin in Tumors and Tumor Vasculature, Shows Potent Anti-Tumor Activity in Human Tumor Models. Cancer Immunol. Immunother. 2007, 56, 447-457. [CrossRef] [PubMed]

94. Sommavilla, R.; Pasche, N.; Trachsel, E.; Giovannoni, L.; Roesli, C.; Villa, A.; Neri, D.; Kaspar, M. Expression, Engineering and Characterization of the Tumor-Targeting Heterodimeric Immunocytokine F8-IL12. Protein Eng. Des. Sel. 2010, 23, 653-661. [CrossRef] [PubMed]

95. Hemmerle, T.; Neri, D. The Antibody-Based Targeted Delivery of Interleukin-4 and 12 to the Tumor Neovasculature Eradicates Tumors in Three Mouse Models of Cancer. Int. J. Cancer 2014, 134, 467-477. [CrossRef] [PubMed]

96. Fallon, J.; Tighe, R.; Kradjian, G.; Guzman, W.; Bernhardt, A.; Neuteboom, B.; Lan, Y.; Sabzevari, H.; Schlom, J.; Greiner, J.W. The Immunocytokine NHS-IL12 as a Potential Cancer Therapeutic. Oncotarget 2014, 5, 1869-1884. [CrossRef]

97. Morillon, Y.M.; Su, Z.; Schlom, J.; Greiner, J.W. Temporal Changes within the (Bladder) Tumor Microenvironment That Accompany the Therapeutic Effects of the Immunocytokine NHS-IL12. J. Immunother. Cancer 2019, 7, 1-11. [CrossRef]

98. Paoloni, M.; Mazcko, C.; Selting, K.; Lana, S.; Barber, L.; Phillips, J.; Skorupski, K.; Vail, D.; Wilson, H.; Biller, B.; et al. Defining the Pharmacodynamic Profile and Therapeutic Index of NHS-IL12 Immunocytokine in Dogs with Malignant Melanoma. PLoS ONE 2015, 10, e0129954. [CrossRef]

99. Steel, J.C.; Waldmann, T.A.; Morris, J.C. Interleukin-15 Biology and Its Therapeutic Implications in Cancer. Trends Pharmacol. Sci. 2012, 33, 35-41. [CrossRef]

100. Kaspar, M.; Trachsel, E.; Neri, D. The Antibody-Mediated Targeted Delivery of Interleukin-15 and GM-CSF to the Tumor Neovasculature Inhibits Tumor Growth and Metastasis. Cancer Res. 2007, 67, 4940-4948. [CrossRef]

101. Dubois, S.; Mariner, J.; Waldmann, T.A.; Tagaya, Y. IL-15R $\alpha$ Recycles and Presents IL-15 in Trans to Neighboring Cells. Immunity 2002, 17, 537-547. [CrossRef]

102. Kermer, V.; Baum, V.; Hornig, N.; Kontermann, R.E.; Müller, D. An Antibody Fusion Protein for Cancer Immunotherapy Mimicking IL-15 Trans-Presentation at the Tumor Site. Mol. Cancer Ther. 2012, 11, 1279-1288. [CrossRef]

103. Vincent, M.; Bessard, A.; Cochonneau, D.; Teppaz, G.; Solé, V.; Maillasson, M.; Birklé, S.; Garrigue-Antar, L.; Quéméner, A.; Jacques, Y. Tumor Targeting of the IL-15 Superagonist RLI by an Anti-GD2 Antibody Strongly Enhances Its Antitumor Potency. Int. J. Cancer 2013, 133, 757-765. [CrossRef]

104. Vincent, M.; Teppaz, G.; Lajoie, L.; Solé, V.; Bessard, A.; Maillasson, M.; Loisel, S.; Béchard, D.; Clémenceau, B.; Thibault, G.; et al. Highly Potent Anti-CD20-RLI Immunocytokine Targeting Established Human B Lymphoma in SCID Mouse. mAbs 2014, 6, 1026-1037. [CrossRef] [PubMed]

105. Metcalf, D. The Colony-Stimulating Factors and Cancer. Cancer Immunol. Res. 2013, 1, 351-356. [CrossRef]

106. Kantoff, P.W.; Higano, C.S.; Shore, N.D.; Berger, E.R.; Small, E.J.; Penson, D.F.; Redfern, C.H.; Ferrari, A.C.; Dreicer, R.; Sims, R.B.; et al. Sipuleucel-T Immunotherapy for Castration-Resistant Prostate Cancer. N. Engl. J. Med. 2010, 363, 411-422. [CrossRef] [PubMed]

107. Dreier, T.; Lode, H.N.; Xiang, R.; Dolman, C.S.; Reisfeld, R.A.; Kang, A.S. Recombinant Immunocytokines Targeting the Mouse Transferrin Receptor: Construction and Biological Activities. Bioconjug. Chem. 1998, 9, 482-489. [CrossRef]

108. Metelitsa, L.S.; Gillies, S.D.; Super, M.; Shimada, H.; Reynolds, C.P.; Seeger, R.C. Antidisialoganglioside/Granulocyte MacrophageColony-Stimulating Factor Fusion Protein Facilitates Neutrophil Antibody-Dependent Cellular Cytotoxicity and Depends on Fc $\gamma$ RII (CD32) and Mac-1 (CD11b/CD18) for Enhanced Effector Cell Adhesion and Azurophil Gr. Blood 2002, 99, $4166-4173$. [CrossRef]

109. Dela Cruz, J.S.; Trinh, K.R.; Morrison, S.L.; Penichet, M.L. Recombinant Anti-Human HER2/ Neu IgG3-(GM-CSF) Fusion Protein Retains Antigen Specificity and Cytokine Function and Demonstrates Antitumor Activity. J. Immunol. 2000, 165, 5112-5121. [CrossRef]

110. Dela Cruz, J.S.; Trinh, K.R.; Chen, H.W.; Ribas, A.; Morrison, S.L.; Penichet, M.L. Anti-HER2/Neu IgG3-(IL-2) and AntiHER2/Neu IgG3-(GM-CSF) Promote HER2/Neu Processing and Presentation by Dendritic Cells: Implications in Immunotherapy and Vaccination Strategies. Mol. Immunol. 2006, 43, 667-676. [CrossRef] [PubMed]

111. Schanzer, J.M.; Fichtner, I.; Baeuerle, P.A.; Kufer, P. Antitumor Activity of a Dual Cytokine/Single-Chain Antibody Fusion Protein for Simultaneous Delivery of GM-CSF and IL-2 to Ep-CAM Expressing Tumor Cells. J. Immunother. 2006, 29, 477-488. [CrossRef] [PubMed]

112. Huang, X.; Molema, G.; King, S.; Watkins, L.; Edgington, T.S.; Thorpe, P.E. Tumor Infarction in Mice by Antibody-Directed Targeting of Tissue Factor to Tumor Vasculature. Science 1997, 275, 547-550. [CrossRef]

113. Ran, S.; Gao, B.; Duffy, S.; Watkins, L.; Rote, N.; Thorpe, P.E. Infarction of Solid Hodgkin's Tumors in Mice by Antibody-Directed Targeting of Tissue Factor to Tumor Vasculature. Cancer Res. 1998, 58, 4646-4653.

114. Nilsson, F.; Kosmehl, H.; Zardi, L.; Neri, D. Targeted Delivery of Tissue Factor to the ED-B Domain of Fibronectin, a Marker of Angiogenesis, Mediates the Infarction of Solid Tumors in Mice. Cancer Res. 2001, 61, 711-716. 
115. Schmid, A.S.; Tintor, D.; Neri, D. Novel Antibody-Cytokine Fusion Proteins Featuring Granulocyte-Colony Stimulating Factor, Interleukin-3 and Interleukin-4 as Payloads. J. Biotechnol. 2018, 271, 29-36. [CrossRef]

116. Hess, C.; Neri, D. Tumor-Targeting Properties of Novel Immunocytokines Based on Murine IL1 $\beta$ and IL6. Protein Eng. Des. Sel. 2014, 27, 207-213. [CrossRef]

117. Hess, C.; Neri, D. The Antibody-Mediated Targeted Delivery of Interleukin-13 to Syngeneic Murine Tumors Mediates a Potent Anticancer Activity. Cancer Immunol. Immunother. 2015, 64, 635-644. [CrossRef]

118. Pasche, N.; Frey, K.; Neri, D. The Targeted Delivery of IL17 to the Mouse Tumor Neo-Vasculature Enhances Angiogenesis but Does Not Reduce Tumor Growth Rate. Angiogenesis 2012, 15, 165-169. [CrossRef]

119. Halin, C.; Niesner, U.; Villani, M.E.; Zardi, L.; Neri, D. Tumor-Targeting Properties of Antibody-Vascular Endothelial Growth Factor Fusion Proteins. Int. J. Cancer 2002, 102, 109-116. [CrossRef] [PubMed]

120. Müller, D.; Frey, K.; Kontermann, R.E. A Novel Antibody-4-1BBL Fusion Protein for Targeted Costimulation in Cancer Immunotherapy. J. Immunother. 2008, 31, 714-722. [CrossRef] [PubMed]

121. Zhang, N.; Sadun, R.E.; Arias, R.S.; Flanagan, M.L.; Sachsman, S.M.; Nien, Y.C.; Khawli, L.A.; Hu, P.; Epstein, A.L. Targeted and Untargeted CD137L Fusion Proteins for the Immunotherapy of Experimental Solid Tumors. Clin. Cancer Res. 2007, 13, $2758-2767$. [CrossRef] [PubMed]

122. Fang, T.; Li, R.; Li, Z.; Cho, J.; Guzman, J.S.; Kamm, R.D.; Ploegh, H.L. Remodeling of the Tumor Microenvironment by a Chemokine/Anti-PD-L1 Nanobody Fusion Protein. Mol. Pharm. 2019, 16, 2838-2844. [CrossRef]

123. Pasche, N.; Woytschak, J.; Wulhfard, S.; Villa, A.; Frey, K.; Neri, D. Cloning and Characterization of Novel Tumor-Targeting Immunocytokines Based on Murine IL7. J. Biotechnol. 2011, 154, 84-92. [CrossRef]

124. Claus, C.; Ferrara, C.; Xu, W.; Sam, J.; Lang, S.; Uhlenbrock, F.; Albrecht, R.; Herter, S.; Schlenker, R.; Hüsser, T.; et al. TumorTargeted 4-1BB Agonists for Combination with T Cell Bispecific Antibodies as off-the-Shelf Therapy. Sci. Transl. Med. 2019, 11, eaav5989. [CrossRef]

125. Gillies, S.D.; Lan, Y.; Hettmann, T.; Brunkhorst, B.; Sun, Y.; Mueller, S.O.; Lo, K.M. A Low-Toxicity IL-2-Based Immunocytokine Retains Antitumor Activity despite Its High Degree of IL-2 Receptor Selectivity. Clin. Cancer Res. 2011, 17, 3673-3685. [CrossRef]

126. Klein, C.; Waldhauer, I.; Nicolini, V.G.; Freimoser-Grundschober, A.; Nayak, T.; Vugts, D.J.; Dunn, C.; Bolijn, M.; Benz, J.; Stihle, M.; et al. Cergutuzumab Amunaleukin (CEA-IL2v), a CEA-Targeted IL-2 Variant-Based Immunocytokine for Combination Cancer Immunotherapy: Overcoming Limitations of Aldesleukin and Conventional IL-2-Based Immunocytokines. OncoImmunology 2017, 6. [CrossRef]

127. Klein, C.; Codarri-Deak, L.; Nicolini, V.; Seeber, S.; Lauener, L.; Richard, M.; Bommer, E.; Karagianni, M.; Sam, J.; Schlenker, R.; et al. Abstract 1552: A Novel PD1-IL2v Immunocytokine for Preferential cis-Activation of IL-2R Signaling on PD-1 Expressing T Cell Subsets Strongly Potentiates Anti-Tumor T Cell Activity of PD-1 Checkpoint Inhibition and IL-2R-Beta-Gamma Agonism. Cancer Res. 2019, 79, 1552. [CrossRef]

128. Sun, Z.; Ren, Z.; Yang, K.; Liu, Z.; Cao, S.; Deng, S.; Xu, L.; Liang, Y.; Guo, J.; Bian, Y.; et al. A Next-Generation Tumor-Targeting IL-2 Preferentially Promotes Tumor-Infiltrating CD $^{8+}$ T-Cell Response and Effective Tumor Control. Nat. Commun. 2019, 10. [CrossRef]

129. List, T.; Casi, G.; Neri, D. A Chemically Defined Trifunctional Antibody-Cytokine-Drug Conjugate with Potent Antitumor Activity. Mol. Cancer Ther. 2014, 13, 2641-2652. [CrossRef] [PubMed]

130. Gillies, S.D. A New Platform for Constructing Antibody-Cytokine Fusion Proteins (Immunocytokines) with Improved Biological Properties and Adaptable Cytokine Activity. Protein Eng. Des. Sel. 2013, 26, 561-569. [CrossRef]

131. Sahin, D.; Arenas-Ramirez, N.; Rath, M.; Karakus, U.; Hümbelin, M.; van Gogh, M.; Borsig, L.; Boyman, O. An IL-2-Grafted Antibody Immunotherapy with Potent Efficacy against Metastatic Cancer. Nat. Commun. 2020, 11, 6440. [CrossRef]

132. Arenas-Ramirez, N.; Zou, C.; Popp, S.; Zingg, D.; Brannetti, B.; Wirth, E.; Calzascia, T.; Kovarik, J.; Sommer, L.; Zenke, G.; et al. Improved Cancer Immunotherapy by a CD25-Mimobody Conferring Selectivity to Human Interleukin-2. Sci. Transl. Med. 2016, 8, 367ra166. [CrossRef]

133. Charych, D.H.; Hoch, U.; Langowski, J.L.; Lee, S.R.; Addepalli, M.K.; Kirk, P.B.; Sheng, D.; Liu, X.; Sims, P.W.; VanderVeen, L.A.; et al. NKTR-214, an Engineered Cytokine with Biased IL2 Receptor Binding, Increased Tumor Exposure, and Marked Efficacy in Mouse Tumor Models. Clin. Cancer Res. 2016, 22, 680. [CrossRef]

134. Charych, D.; Khalili, S.; Dixit, V.; Kirk, P.; Chang, T.; Langowski, J.; Rubas, W.; Doberstein, S.K.; Eldon, M.; Hoch, U.; et al. Modeling the Receptor Pharmacology, Pharmacokinetics, and Pharmacodynamics of NKTR-214, a Kinetically-Controlled Interleukin-2 (IL2) Receptor Agonist for Cancer Immunotherapy. PLoS ONE 2017, 12, e0179431. [CrossRef]

135. Sharma, M.; Khong, H.; Fa'ak, F.; Bentebibel, S.-E.; Janssen, L.M.E.; Chesson, B.C.; Creasy, C.A.; Forget, M.-A.; Kahn, L.M.S.; Pazdrak, B.; et al. Bempegaldesleukin Selectively Depletes Intratumoral Tregs and Potentiates T Cell-Mediated Cancer Therapy. Nat. Commun. 2020, 11, 661. [CrossRef]

136. Bentebibel, S.-E.; Hurwitz, M.E.; Bernatchez, C.; Haymaker, C.; Hudgens, C.W.; Kluger, H.M.; Tetzlaff, M.T.; Tagliaferri, M.A.; Zalevsky, J.; Hoch, U.; et al. A First-in-Human Study and Biomarker Analysis of NKTR-214, a Novel IL2R $\beta \gamma$-Biased Cytokine, in Patients with Advanced or Metastatic Solid Tumors. Cancer Discov. 2019, 9, 711. [CrossRef] [PubMed]

137. Diab, A.; Tannir, N.M.; Bentebibel, S.-E.; Hwu, P.; Papadimitrakopoulou, V.; Haymaker, C.; Kluger, H.M.; Gettinger, S.N.; Sznol, M.; Tykodi, S.S.; et al. Bempegaldesleukin (NKTR-214) plus Nivolumab in Patients with Advanced Solid Tumors: Phase I Dose-Escalation Study of Safety, Efficacy, and Immune Activation (PIVOT-02). Cancer Discov. 2020, 10, 1158-1173. [CrossRef] 
138. Huddart, R.A.; Siefker-Radtke, A.O.; Balar, A.V.; Bilen, M.A.; Powles, T.; Bamias, A.; Castellano, D.; Khalil, M.F.; Van Der Heijden, M.S.; Koshkin, V.S.; et al. PIVOT-10: Phase II Study of Bempegaldesleukin plus Nivolumab in Cisplatin-Ineligible Advanced Urothelial Cancer. Future Oncol. Lond. Engl. 2021, 17, 137-149. [CrossRef] [PubMed]

139. Khushalani, N.I.; Diab, A.; Ascierto, P.A.; Larkin, J.; Sandhu, S.; Sznol, M.; Koon, H.B.; Jarkowski, A.; Zhou, M.; Statkevich, P.; et al. Bempegaldesleukin plus Nivolumab in Untreated, Unresectable or Metastatic Melanoma: Phase III PIVOT IO 001 Study Design. Future Oncol. Lond. Engl. 2020, 16, 2165-2175. [CrossRef] [PubMed]

140. Garcin, G.; Paul, F.; Staufenbiel, M.; Bordat, Y.; Van der Heyden, J.; Wilmes, S.; Cartron, G.; Apparailly, F.; De Koker, S.; Piehler, J.; et al. High Efficiency Cell-Specific Targeting of Cytokine Activity. Nat. Commun. 2014, 5, 3016. [CrossRef] [PubMed]

141. Pogue, S.L.; Taura, T.; Bi, M.; Yun, Y.; Sho, A.; Mikesell, G.; Behrens, C.; Sokolovsky, M.; Hallak, H.; Rosenstock, M.; et al. Targeting Attenuated Interferon- $\alpha$ to Myeloma Cells with a CD38 Antibody Induces Potent Tumor Regression with Reduced off-Target Activity. PLoS ONE 2016, 11, e0162472. [CrossRef]

142. Cauwels, A.; Van Lint, S.; Garcin, G.; Bultinck, J.; Paul, F.; Gerlo, S.; Van der Heyden, J.; Bordat, Y.; Catteeuw, D.; De Cauwer, L.; et al. A Safe and Highly Efficient Tumor-Targeted Type I Interferon Immunotherapy Depends on the Tumor Microenvironment. OncoImmunology 2018, 7. [CrossRef]

143. Huyghe, L.; Van Parys, A.; Cauwels, A.; Van Lint, S.; De Munter, S.; Bultinck, J.; Zabeau, L.; Hostens, J.; Goethals, A.; Vanderroost, N.; et al. Safe Eradication of Large Established Tumors Using Neovasculature-targeted Tumor Necrosis Factor-based Therapies. EMBO Mol. Med. 2020, 12, 1-15. [CrossRef] [PubMed]

144. De Luca, R.; Neri, D. Potentiation of PD-L1 Blockade with a Potency-Matched Dual Cytokine-Antibody Fusion Protein Leads to Cancer Eradication in BALB/c-Derived Tumors but Not in Other Mouse Strains. Cancer Immunol. Immunother. 2018, 67, 1381-1391. [CrossRef] [PubMed]

145. Venetz, D.; Koovely, D.; Weder, B.; Neri, D. Targeted Reconstitution of Cytokine Activity upon Antigen Binding Using Split Cytokine Antibody Fusion Proteins. J. Biol. Chem. 2016, 291, 18139-18147. [CrossRef]

146. Holden, S.A.; Lan, Y.; Pardo, A.M.; Wesolowski, J.S.; Gillies, S.D.; Gillies, S.D. Augmentation of Antitumor Activity of an Antibody-Interleukin 2 Immunocytokine with Chemotherapeutic Agents. Clin. Cancer Res. 2001, 7, $2862-2869$.

147. Moschetta, M.; Pretto, F.; Berndt, A.; Galler, K.; Richter, P.; Bassi, A.; Oliva, P.; Micotti, E.; Valbusa, G.; Schwager, K.; et al. Paclitaxel Enhances Therapeutic Efficacy of the F8-IL2 Immunocytokine to EDA-Fibronectin-Positive Metastatic Human Melanoma Xenografts. Cancer Res. 2012, 72, 1814-1824. [CrossRef] [PubMed]

148. Pretto, F.; Elia, G.; Castioni, N.; Neri, D. Preclinical Evaluation of IL2-Based Immunocytokines Supports Their Use in Combination with Dacarbazine, Paclitaxel and TNF-Based Immunotherapy. Cancer Immunol. Immunother. 2014, 63, 901-910. [CrossRef] [PubMed]

149. Mårlind, J.; Kaspar, M.; Trachsel, E.; Sommavilla, R.; Hindle, S.; Bacci, C.; Giovannon, L.; Neri, D. Antibody-Mediated Delivery of Interleukin-2 to the Stroma of Breast Cancer Strongly Enhances the Potency of Chemotherapy. Clin. Cancer Res. 2008, 14, 6515-6524. [CrossRef]

150. Pedretti, M.; Verpelli, C.; Mårlind, J.; Bertani, G.; Sala, C.; Neri, D.; Bello, L. Combination of Temozolomide with Immunocytokine F16-IL2 for the Treatment of Glioblastoma. Br. J. Cancer 2010, 103, 827-836. [CrossRef] [PubMed]

151. Lyu, M.; Kurzrock, R.; Rosenblum, M.G. The Immunocytokine ScFv23/TNF Targeting HER-2/Neu Induces Synergistic Cytotoxic Effects with 5-Fluorouracil in TNF-Resistant Pancreatic Cancer Cell Lines. Biochem. Pharmacol. 2008, 75, 836-846. [CrossRef]

152. Hemmerle, T.; Probst, P.; Giovannoni, L.; Green, A.J.; Meyer, T.; Neri, D. The Antibody-Based Targeted Delivery of TNF in Combination with Doxorubicin Eradicates Sarcomas in Mice and Confers Protective Immunity. Br. J. Cancer 2013, 109, 1206-1213. [CrossRef]

153. Corbellari, R.; Nadal, L.; Villa, A.; Neri, D.; Luca, R. De The Immunocytokine L19-TNF Eradicates Sarcomas in Combination with Chemotherapy Agents or with Immune Check-Point Inhibitors. Anticancer Drugs 2020, 31, 799-805. [CrossRef]

154. Pasche, N.; Wulhfard, S.; Pretto, F.; Carugati, E.; Neri, D. The Antibody-Based Delivery of Interleukin-12 to the Tumor Neovasculature Eradicates Murine Models of Cancer in Combination with Paclitaxel. Clin. Cancer Res. 2012, 18, 4092-4104. [CrossRef]

155. Demaria, S.; Golden, E.B.; Formenti, S.C. Role of Local Radiation Therapy in Cancer Immunotherapy. JAMA Oncol. 2015, 1, 1325-1332. [CrossRef]

156. Morris, Z.S.; Guy, E.I.; Francis, D.M.; Gressett, M.M.; Lauren, R.; Carmichael, L.L.; Yang, R.K.; Armstrong, E.A.; Navid, F.; Gillies, S.D.; et al. In Situ Tumor Vaccination by Combining Local Radiation and Tumor-Specific Antibody or Immunocytokine Treatments. Cancer Res. 2016, 76, 3929-3941. [CrossRef]

157. Clark, P.A.; Sriramaneni, R.N.; Jin, W.J.; Jagodinsky, J.C.; Bates, A.M.; Jaquish, A.A.; Anderson, B.R.; Le, T.; Lubin, J.A.; Chakravarty, I.; et al. In Situ Vaccination at a Peripheral Tumor Site Augments Response against Melanoma Brain Metastases. J. Immunother. Cancer 2020, 8, 1-15. [CrossRef] [PubMed]

158. Morris, Z.S.; Guy, E.I.; Werner, L.R.; Carlson, P.M.; Clinton, M.; Kler, J.S.; Busche, S.M.; Jaquish, A.A.; Sriramaneni, R.N.; Carmichael, L.L.; et al. Tumor-Specific Inhibition of in Situ Vaccination by Distant Untreated Tumor Sites. Cancer Immunol. Res. 2018, 6, 825-834. [CrossRef] [PubMed]

159. Rekers, N.H.; Olivo Pimentel, V.; Yaromina, A.; Lieuwes, N.G.; Biemans, R.; Zegers, C.M.L.; Germeraad, W.T.V.; Van Limbergen, E.J.; Neri, D.; Dubois, L.J.; et al. The Immunocytokine L19-IL2: An Interplay between Radiotherapy and Long-Lasting Systemic Anti-Tumour Immune Responses. OncoImmunology 2018, 7. [CrossRef] 
160. Zegers, C.M.L.; Rekers, N.H.; Quaden, D.H.F.; Lieuwes, N.G.; Yaromina, A.; Germeraad, W.T.V.; Wieten, L.; Biessen, E.A.L.; Boon, L.; Neri, D.; et al. Radiotherapy Combined with the Immunocytokine L19-IL2 Provides Long-Lasting Antitumor Effects. Clin. Cancer Res. 2015, 21, 1151-1160. [CrossRef] [PubMed]

161. Rekers, N.H.; Zegers, C.M.L.; Yaromina, A.; Lieuwes, N.G.; Biemans, R.; Senden-Gijsbers, B.L.M.G.; Losen, M.; Van Limbergen, E.J.; Germeraad, W.T.V.; Neri, D.; et al. Combination of Radiotherapy with the Immunocytokine L19-IL2: Additive Effect in a NK Cell Dependent Tumour Model. Radiother. Oncol. 2015, 116, 438-442. [CrossRef]

162. Voeller, J.; Erbe, A.K.; Slowinski, J.; Rasmussen, K.; Carlson, P.M.; Hoefges, A.; Vandenheuvel, S.; Stuckwisch, A.; Wang, X.; Gillies, S.D.; et al. Combined Innate and Adaptive Immunotherapy Overcomes Resistance of Immunologically Cold Syngeneic Murine Neuroblastoma to Checkpoint Inhibition. J. ImmunoTher. Cancer 2019, 6, 344. [CrossRef]

163. Johnson, E.E.; Yamane, B.H.; Buhtoiarov, I.N.; Lum, H.D.; Rakhmilevich, A.L.; Mahvi, D.M.; Gillies, S.D.; Sondel, P.M. Radiofrequency Ablation Combined with KS-IL2 Immunocytokine (EMD 273066) Results in an Enhanced Antitumor Effect against Murine Colon Adenocarcinoma. Clin. Cancer Res. 2009, 15, 4875-4884. [CrossRef]

164. Kujawski, M.; Sherman, M.; Hui, S.; Zuro, D.; Lee, W.H.; Yazaki, P.; Sherman, A.; Szpikowska, B.; Chea, J.; Lasiewski, D.; et al. Potent Immunomodulatory Effects of an Anti-CEA-IL-2 Immunocytokine on Tumor Therapy and Effects of Stereotactic Radiation. OncoImmunology 2020, 9, 1-14. [CrossRef]

165. Maria, N.S.S.; Barnes, S.R.; Weist, M.R.; Colcher, D.; Raubitschek, A.A.; Jacobs, R.E. Low Dose Focused Ultrasound Induces Enhanced Tumor Accumulation of Natural Killer Cells. PLOS ONE 2015, 10, e0142767. [CrossRef]

166. Eckert, F.; Schmitt, J.; Zips, D.; Krueger, M.A.; Pichler, B.J.; Gillies, S.D.; Strittmatter, W.; Handgretinger, R.; Schilbach, K. Enhanced Binding of Necrosis-Targeting Immunocytokine NHS-IL12 after Local Tumour Irradiation in Murine Xenograft Models. Cancer Immunol. Immunother. 2016, 65, 1003-1013. [CrossRef]

167. Eckert, F.; Jelas, I.; Oehme, M.; Huber, S.M.; Sonntag, K.; Welker, C.; Gillies, S.D.; Strittmatter, W.; Zips, D.; Handgretinger, R.; et al. Tumor-Targeted IL-12 Combined with Local Irradiation Leads to Systemic Tumor Control via Abscopal Effects in Vivo. OncoImmunology 2017, 6, 1-12. [CrossRef] [PubMed]

168. Maloney, D.G.; Grillo-López, A.J.; Bodkin, D.J.; White, C.A.; Liles, T.M.; Royston, I.; Varns, C.; Rosenberg, J.; Levy, R. Idec-C2b8: Results of a Phase I Multiple-Dose Trial in Patients with Relapsed Non-Hodgkin's Lymphoma. J. Clin. Oncol. 1997, 15, 3266-3274. [CrossRef] [PubMed]

169. Börschel, N.; Schwöppe, C.; Zerbst, C.; Angenendt, L.; Kessler, T.; Klapper, W.; Giovannoni, L.; Elia, G.; Neri, D.; Berdel, W.E.; et al. Potentiating the Activity of Rituximab against Mantle Cell Lymphoma in Mice by Targeting Interleukin-2 to the Neovasculature. Leuk. Res. 2015, 39, 739-748. [CrossRef]

170. Schliemann, C.; Palumbo, A.; Zuberbühler, K.; Villa, A.; Kaspar, M.; Trachsel, E.; Klapper, W.; Menssen, H.D.; Neri, D. Complete Eradication of Human B-Cell Lymphoma Xenografts Using Rituximab in Combination with the Immunocytokine L19-IL2. Blood 2009, 113, 2275-2283. [CrossRef]

171. Orecchia, P.; Conte, R.; Balza, E.; Pietra, G.; Mingari, M.C.; Carnemolla, B. Targeting Syndecan-1, a Molecule Implicated in the Process of Vasculogenic Mimicry, Enhances the Therapeutic Efficacy of the L19-IL2 Immunocytokine in Human Melanoma Xenografts. Oncotarget 2015, 6, 37426-37442. [CrossRef]

172. Orecchia, P.; Balza, E.; Pietra, G.; Conte, R.; Bizzarri, N.; Ferrero, S.; Mingari, M.C.; Carnemolla, B. L19-IL2 Immunocytokine in Combination with the Anti-Syndecan-1 46F2SIP Antibody Format: A New Targeted Treatment Approach in an Ovarian Carcinoma Model. Cancers 2019, 11, 1-19. [CrossRef]

173. Murer, P.; Kiefer, J.D.; Plüss, L.; Matasci, M.; Blümich, S.L.; Stringhini, M.; Neri, D. Targeted Delivery of TNF Potentiates the Antibody-Dependent Cell-Mediated Cytotoxicity of an Anti-Melanoma Immunoglobulin. J. Investig. Dermatol. 2019, 139, 1339-1348. [CrossRef]

174. Fallon, J.K.; Vandeveer, A.J.; Schlom, J.; Greiner, J.W. Enhanced Antitumor Effects by Combining an IL-12/ Anti-DNA Fusion Protein with Avelumab, an Anti-PD-L1 Antibody. Oncotarget 2017, 8, 20558-20571. [CrossRef]

175. Xu, C.; Zhang, Y.; Alexander Rolfe, P.; Hernández, V.M.; Guzman, W.; Kradjian, G.; Marelli, B.; Qin, G.; Qi, J.; Wang, H.; et al. Combination Therapy with NHS-MuIL12 and Avelumab (Anti-PD-L1) Enhances Antitumor Efficacy in Preclinical Cancer Models. Clin. Cancer Res. 2017, 23, 5869-5880. [CrossRef] [PubMed]

176. Rakhmilevich, A.L.; Felder, M.; Lever, L.; Slowinski, J.; Rasmussen, K.; Hoefges, A.; Van De Voort, T.J.; Loibner, H.; Korman, A.J.; Gillies, S.D.; et al. Effective Combination of Innate and Adaptive Immunotherapeutic Approaches in a Mouse Melanoma Model. J. Immunol. 2017, 198, 1575-1584. [CrossRef] [PubMed]

177. Schwager, K.; Hemmerle, T.; Aebischer, D.; Neri, D. The Immunocytokine L19-IL2 Eradicates Cancer When Used in Combination with CTLA-4 Blockade or with L19-TNF. J. Investig. Dermatol. 2013, 133, 751-758. [CrossRef] [PubMed]

178. Neal, Z.C.; Yang, J.C.; Rakhmilevich, A.L.; Buhtoiarov, I.N.; Lum, H.E.; Imboden, M.; Hank, J.A.; Lode, H.N.; Reisfeld, R.A.; Gillies, S.D.; et al. Enhanced Activity of Hu14.18-IL2 Immunocytokine against Murine NXS2 Neuroblastoma When Combined with Interleukin 2 Therapy. Clin. Cancer Res. 2004, 10, 4839-4847. [CrossRef] [PubMed]

179. Neal, Z.C.; Sondel, P.M.; Bates, M.K.; Gillies, S.D.; Herweijer, H. Flt3-L Gene Therapy Enhances Immunocytokine-Mediated Antitumor Effects and Induces Long-Term Memory. Cancer Immunol. Immunother. 2007, 56, 1765-1774. [CrossRef]

180. Schilbach, K.; Alkhaled, M.; Welker, C.; Eckert, F.; Blank, G.; Ziegler, H.; Sterk, M.; Müller, F.; Sonntag, K.; Wieder, T.; et al. CancerTargeted IL-12 Controls Human Rhabdomyosarcoma by Senescence Induction and Myogenic Differentiation. OncoImmunology 2015, 4, 1-14. [CrossRef] [PubMed] 
181. Bauer, S.; Adrian, N.; Siebenborn, U.; Fadle, N.; Plesko, M.; Fischer, E.; Wüest, T.; Stenner, F.; Mertens, J.C.; Knuth, A.; et al. Sequential Cancer Immunotherapy: Targeted Activity of Dimeric TNF and IL-8. Cancer Immun. 2009, 9, 1-10. [CrossRef]

182. Menssen, H.D.; Harnack, U.; Erben, U.; Neri, D.; Hirsch, B.; Dürkop, H. Antibody-Based Delivery of Tumor Necrosis Factor $(\mathrm{L} 19-\mathrm{TNF} \alpha)$ and Interleukin-2 (L19-IL2) to Tumor-Associated Blood Vessels Has Potent Immunological and Anticancer Activity in the Syngeneic J558L BALB/c Myeloma Model. J. Cancer Res. Clin. Oncol. 2018, 144, 499-507. [CrossRef]

183. Chen, P.; Nogusa, S.; Thapa, R.J.; Shaller, C.; Simmons, H.; Peri, S.; Adams, G.P.; Balachandran, S. Anti-CD70 Immunocytokines for Exploitation of Interferon- $\gamma$-Induced RIP1-Dependent Necrosis in Renal Cell Carcinoma. PLoS ONE 2013, 8, e0061446. [CrossRef]

184. Dakhel, S.; Ongaro, T.; Gouyou, B.; Matasci, M.; Villa, A.; Neri, D.; Cazzamalli, S. Targeted Enhancement of the Therapeutic Window of L19-TNF by Transient and Selective Inhibition of RIPK1-Signaling Cascade. Oncotarget 2019, 10, 6678-6690. [CrossRef]

185. Frey, K.; Schliemann, C.; Schwager, K.; Giavazzi, R.; Johannsen, M.; Neri, D. The Immunocytokine F8-IL2 Improves the Therapeutic Performance of Sunitinib in a Mouse Model of Renal Cell Carcinoma. J. Urol. 2010, 184, 2540-2548. [CrossRef]

186. Aigner, M.; Janke, M.; Lulei, M.; Beckhove, P.; Fournier, P.; Schirrmacher, V. An Effective Tumor Vaccine Optimized for Costimulation via Bispecific and Trispecific Fusion Proteins. Int. J. Oncol. 2008, 32, 777-789.

187. Fournier, P.; Aigner, M.; Schirrmacher, V. Transcriptome Analysis and Cytokine Profiling of Naive T Cells Stimulated by a Tumor Vaccine via CD3 and CD25. Int. J. Oncol. 2010, 37. [CrossRef]

188. Fournier, P.; Aigner, M.; Schirrmacher, V. Targeting of IL-2 and GM-CSF Immunocytokines to a Tumor Vaccine Leads to Increased Anti-Tumor Activity. Int. J. Oncol. 2011, 38, 1719-1729. [CrossRef] [PubMed]

189. Huang, X.; Ye, D.; Thorpe, P.E. Enhancing the Potency of a Whole-Cell Breast Cancer Vaccine in Mice with an Antibody-IL-2 Immunocytokine That Targets Exposed Phosphatidylserine. Vaccine 2011, 29, 4785-4793. [CrossRef]

190. Smalley Rumfield, C.; Pellom, S.T.; Morillon, Y.M.; Schlom, J.; Jochems, C. Immunomodulation to Enhance the Efficacy of an HPV Therapeutic Vaccine. J. Immunother. Cancer 2020, 8. [CrossRef] [PubMed]

191. Vijayakumar, G.; McCroskery, S.; Palese, P. Engineering Newcastle Disease Virus as an Oncolytic Vector for Intratumoral Delivery of Immune Checkpoint Inhibitors and Immunocytokines. J. Virol. 2019, 94, 1-14. [CrossRef]

192. Soto, B.L.; Hank, J.A.; Darjatmoko, S.R.; Polans, A.S.; Yanke, E.M.; Rakhmilevich, A.L.; Seo, S.; Kim, K.; Reisfeld, R.A.; Gillies, S.D.; et al. Anti-Tumor and Immunomodulatory Activity of Resveratrol in Vitro and Its Potential for Combining with Cancer Immunotherapy. Int. Immunopharmacol. 2011, 11, 1877-1886. [CrossRef] [PubMed]

193. Soto, B.L.; Hank, J.A.; Van De Voort, T.J.; Subramanian, L.; Polans, A.S.; Rakhmilevich, A.L.; Yang, R.K.; Seo, S.; Kim, K.; Reisfeld, R.A.; et al. The Anti-Tumor Effect of Resveratrol Alone or in Combination with Immunotherapy in a Neuroblastoma Model. Cancer Immunol. Immunother. 2011, 60, 731-738. [CrossRef] [PubMed]

194. Singh, H.; Serrano, L.M.; Pfeiffer, T.; Olivares, S.; McNamara, G.; Smith, D.D.; Al-Kadhimi, Z.; Forman, S.J.; Gillies, S.D.; Jensen, M.C.; et al. Combining Adoptive Cellular and Immunocytokine Therapies to Improve Treatment of B-Lineage Malignancy. Cancer Res. 2007, 67, 2872-2880. [CrossRef]

195. King, D.M.; Albertini, M.R.; Schalch, H.; Hank, J.A.; Gan, J.; Surfus, J.; Mahvi, D.; Schiller, J.H.; Warner, T.; Kim, K.M.; et al. Phase I Clinical Trial of the Immunocytokine EMD 273063 in Melanoma Patients. J. Clin. Oncol. 2004, 22, 4463-4473. [CrossRef]

196. Osenga, K.L.; Hank, J.A.; Albertini, M.R.; Gan, J.; Sternberg, A.G.; Eickhoff, J.; Seeger, R.C.; Matthay, K.K.; Reynolds, C.P.; Krailo, M.; et al. A Phase I Clinical Trial of the Hu14.18-IL2 (EMD 273063) as a Treatment for Children with Refractory or Recurrent Neuroblastoma and Melanoma: A Study of the Children's Oncology Group. Clin. Cancer Res. 2006, 12, 1750-1759. [CrossRef]

197. Ribas, A.; Kirkwood, J.M.; Atkins, M.B.; Whiteside, T.L.; Gooding, W.; Kovar, A.; Gillies, S.D.; Kashala, O.; Morse, M.A. Phase I/II Open-Label Study of the Biologic Effects of the Interleukin-2 Immunocytokine EMD 273063 (Hu14.18-IL2) in Patients with Metastatic Malignant Melanoma. J. Transl. Med. 2009, 7, 1-11. [CrossRef] [PubMed]

198. Albertini, M.R.; Hank, J.A.; Gadbaw, B.; Kostlevy, J.; Haldeman, J.; Schalch, H.; Gan, J.; Kim, K.M.; Eickhoff, J.; Gillies, S.D.; et al. Phase II Trial of Hu14.18-IL2 for Patients with Metastatic Melanoma. Cancer Immunol. Immunother. 2012, 61, 2261-2271. [CrossRef]

199. Shusterman, S.; London, W.B.; Gillies, S.D.; Hank, J.A.; Voss, S.D.; Seeger, R.C.; Reynolds, C.P.; Kimball, J.; Albertini, M.R.; Wagner, B.; et al. Antitumor Activity of Hu14.18-IL2 in Patients with Relapsed/Refractory Neuroblastoma: A Children's Oncology Group (COG) Phase II Study. J. Clin. Oncol. 2010, 28, 4969-4975. [CrossRef] [PubMed]

200. Albertini, M.R.; Yang, R.K.; Ranheim, E.A.; Hank, J.A.; Zuleger, C.L.; Weber, S.; Neuman, H.; Hartig, G.; Weigel, T.; Mahvi, D.; et al. Pilot Trial of the Hu14.18-IL2 Immunocytokine in Patients with Completely Resectable Recurrent Stage III or Stage IV Melanoma. Cancer Immunol. Immunother. 2018, 67, 1647-1658. [CrossRef]

201. Shusterman, S.; Naranjo, A.; van Ryn, C.; Hank, J.A.; Parisi, M.T.; Shulkin, B.L.; Servaes, S.; London, W.B.; Shimada, H.; Gan, J.; et al. Antitumor Activity and Tolerability of Hu14.18-IL2 with GMCSF and Isotretinoin in Recurrent or Refractory Neuroblastoma: A Children's Oncology Group Phase II Study. Clin. Cancer Res. 2019, 25, 6044-6051. [CrossRef] [PubMed]

202. Hank, J.A.; Gan, J.; Ryu, H.; Ostendorf, A.; Stauder, M.C.; Sternberg, A.; Albertini, M.; Lo, K.M.; Gillies, S.D.; Eickhoff, J.; et al. Immunogenicity of the Hu14.18-IL2 Immunocytokine Molecule in Adults with Melanoma and Children with Neuroblastoma. Clin. Cancer Res. 2009, 15, 5923-5930. [CrossRef] [PubMed]

203. Delgado, D.C.; Hank, J.A.; Kolesar, J.; Lorentzen, D.; Gan, J.; Seo, S.; Kim, K.M.; Shusterman, S.; Gillies, S.D.; Reisfeld, R.A.; et al. Genotypes of NK Cell KIR Receptors, Their Ligands, and Fc $\gamma$ Receptors in the Response of Neuroblastoma Patients to Hu14.18-IL2 Immunotherapy. Cancer Res. 2010, 70, 9554-9561. [CrossRef] [PubMed] 
204. Yang, R.K.; Kuznetsov, I.B.; Ranheim, E.A.; Wei, J.S.; Sindiri, S.; Gryder, B.E.; Gangalapudi, V.; Song, Y.K.; Patel, V.; Hank, J.A.; et al. Outcome-Related Signatures Identified by Whole Transcriptome Sequencing of Resectable Stage III/IV Melanoma Evaluated after Starting Hu14.18-IL2. Clin. Cancer Res. Off. J. Am. Assoc. Cancer Res. 2020, 26, 3296-3306. [CrossRef] [PubMed]

205. Shusterman, S.; London, W.B.; Hank, J.A.; Parisi, M.T.; Shulkin, B.L.; Servaes, S.-E.-N.; Naranjo, A.; Shimada, H.; Gan, J.; Gillies, S.; et al. A Feasibility and Phase II Study of the Hu14.18-IL2 Immunocytokine in Combination with GM-CSF and Isotretinoin in Patients with Recurrent or Refractory Neuroblastoma: A Children's Oncology Group Study. J. Clin. Oncol. 2015, $33,10017$. [CrossRef]

206. Catania, C.; Maur, M.; Berardi, R.; Rocca, A.; Di Giacomo, A.M.; Spitaleri, G.; Masini, C.; Pierantoni, C.; González-Iglesias, R.; Zigon, G.; et al. The Tumor-Targeting Immunocytokine F16-IL2 in Combination with Doxorubicin: Dose Escalation in Patients with Advanced Solid Tumors and Expansion into Patients with Metastatic Breast Cancer. Cell Adhes. Migr. 2015, 9, 14-21. [CrossRef]

207. Schliemann, C.; Gutbrodt, K.L.; Kerkhoff, A.; Pohlen, M.; Wiebe, S.; Silling, G.; Angenendt, L.; Kessler, T.; Mesters, R.M.; Giovannoni, L.; et al. Targeting Interleukin-2 to the Bone Marrow Stroma for Therapy of Acute Myeloid Leukemia Relapsing after Allogeneic Hematopoietic Stem Cell Transplantation. Cancer Immunol. Res. 2015, 3, 547-556. [CrossRef]

208. De Braud, F.G.; Catania, C.; Masini, C.; Maur, M.; Cascinu, S.; Berardi, R.; Giovannoni, L.; Spitaleri, G.; Boselli, S.; Neri, D. Combinations of the Immunocytokine F16-IL2 with Doxorubicin or with Paclitaxel Investigated in Phase Ib Studies in Patients with Advanced Solid Tumors. J. Clin. Oncol. 2010, 28, e13017. [CrossRef]

209. De Braud, F.G.; Catania, C.; Onofri, A.; Pierantoni, C.; Cascinu, S.; Maur, M.; Masini, C.; Conte, P.F.; Giovannoni, L.; Tasciotti, A.; et al. Combination of the Immunocytokine F16-IL2 with Doxorubicin or Paclitaxel in Patients with Solid Tumors: Results from Two Phase Ib Trials. J. Clin. Oncol. 2011, 29, 2595. [CrossRef]

210. Connor, J.P.; Cristea, M.C.; Lewis, N.L.; Lewis, L.D.; Komarnitsky, P.B.; Mattiacci, M.R.; Felder, M.; Stewart, S.; Harter, J.; HensleeDowney, J.; et al. A Phase 1b Study of Humanized KS-Interleukin-2 (HuKS-IL2) Immunocytokine with Cyclophosphamide in Patients with EpCAM-Positive Advanced Solid Tumors. BMC Cancer 2013, 13, 1. [CrossRef]

211. Gladkov, O.; Ramlau, R.; Serwatowski, P.; Milanowski, J.; Tomeczko, J.; Komarnitsky, P.B.; Kramer, D.; Krzakowski, M.J. Cyclophosphamide and Tucotuzumab (HuKS-IL2) Following First-Line Chemotherapy in Responding Patients with ExtensiveDisease Small-Cell Lung Cancer. Anticancer. Drugs 2015, 26, 1061-1068. [CrossRef]

212. Ko, Y.-J.; Bubley, G.J.; Weber, R.; Redfern, C.; Gold, D.P.; Finke, L.; Kovar, A.; Dahl, T.; Gillies, S.D. Safety, Pharmacokinetics, and Biological Pharmacodynamics of the Immunocytokine EMD 273066 (HuKS-IL2). J. Immunother. 2004, 27, 232-239. [CrossRef] [PubMed]

213. Spitaleri, G.; Berardi, R.; Pierantoni, C.; De Pas, T.; Noberasco, C.; Libbra, C.; González-Iglesias, R.; Giovannoni, L.; Tasciotti, A.; Neri, D.; et al. Phase I/II Study of the Tumour-Targeting Human Monoclonal Antibody-Cytokine Fusion Protein L19-TNF in Patients with Advanced Solid Tumours. J. Cancer Res. Clin. Oncol. 2013, 139, 447-455. [CrossRef] [PubMed]

214. Weide, B.; Eigentler, T.K.; Pflugfelder, A.; Zelba, H.; Martens, A.; Pawelec, G.; Giovannoni, L.; Ruffini, P.A.d.; Elia, G.; Neri, D.; et al. Intralesional Treatment of Stage III Metastatic Melanoma Patients with L19-IL2 Results in Sustained Clinical and Systemic Immunologic Responses. Cancer Immunol. Res. 2014, 2, 668-678. [CrossRef]

215. Danielli, R.; Patuzzo, R.; Di Giacomo, A.M.; Gallino, G.; Maurichi, A.; Di Florio, A.; Cutaia, O.; Lazzeri, A.; Fazio, C.; Miracco, C.; et al. Intralesional Administration of L19-IL2/L19-TNF in Stage III or Stage IVM1a Melanoma Patients: Results of a Phase II Study. Cancer Immunol. Immunother. 2015, 64, 999-1009. [CrossRef]

216. Eigentler, T.K.; Weide, B.; De Braud, F.; Spitaleri, G.; Romanini, A.; Pflugfelder, A.; Gonzalez-Iglesias, R.; Tasciotti, A.; Giovannoni, L.; Schwager, K.; et al. A Dose-Escalation and Signal-Generating Study of the Immunocytokine L19-IL2 in Combination with Dacarbazine for the Therapy of Patients with Metastatic Melanoma. Clin. Cancer Res. 2011, 17, 7732-7742. [CrossRef]

217. Weide, B.; Eigentler, T.; Catania, C.; Ascierto, P.A.; Cascinu, S.; Becker, J.C.; Hauschild, A.; Romanini, A.; Danielli, R.; Dummer, R.; et al. A Phase II Study of the L19IL2 Immunocytokine in Combination with Dacarbazine in Advanced Metastatic Melanoma Patients. Cancer Immunol. Immunother. 2019, 68, 1547-1559. [CrossRef]

218. Johannsen, M.; Spitaleri, G.; Curigliano, G.; Roigas, J.; Weikert, S.; Kempkensteffen, C.; Roemer, A.; Kloeters, C.; Rogalla, P.; Pecher, G.; et al. The Tumour-Targeting Human L19-IL2 Immunocytokine: Preclinical Safety Studies, Phase i Clinical Trial in Patients with Solid Tumours and Expansion into Patients with Advanced Renal Cell Carcinoma. Eur. J. Cancer 2010, 46, $2926-2935$. [CrossRef] [PubMed]

219. Rudman, S.M.; Jameson, M.B.; Mckeage, M.J.; Savage, P.; Jodrell, D.I.; Harries, M.; Acton, G. A Phase 1 Study of AS1409, a Novel Antibody-Cytokine Fusion Protein, in Patients with Malignant Melanoma or Renal Cell Carcinoma. Clin. Cancer Res. 2011, 17, 1998-2005. [CrossRef] [PubMed]

220. Papadia, F.; Basso, V.; Patuzzo, R.; Maurichi, A.; Di Florio, A.; Zardi, L.; Ventura, E.; González-Iglesias, R.; Lovato, V.; Giovannoni, L.; et al. Isolated Limb Perfusion with the Tumor-Targeting Human Monoclonal Antibody-Cytokine Fusion Protein L19-TNF plus Melphalan and Mild Hyperthermia in Patients with Locally Advanced Extremity Melanoma. J. Surg. Oncol. 2013, 107, 173-179. [CrossRef]

221. Lieverse, R.I.Y.; Van Limbergen, E.J.; Oberije, C.J.G.; Troost, E.G.C.; Hadrup, S.R.; Dingemans, A.M.C.; Hendriks, L.E.L.; Eckert, F.; Hiley, C.; Dooms, C.; et al. Stereotactic Ablative Body Radiotherapy (SABR) Combined with Immunotherapy (L19-IL2) versus Standard of Care in Stage IV NSCLC Patients, ImmunoSABR: A Multicentre, Randomised Controlled Open-Label Phase II Trial. BMC Cancer 2020, 20, 1-10. [CrossRef] 
222. Spicer, J.F.; Jameson, M.B.; Savage, P.; Jodrell, D.; Rudman, S.M.; Erlandsson, F.; Acton, G.; McKeage, M. A Phase I Study of AS1409, a Novel Antibody-Cytokine Fusion Protein, in Patients with Malignant Melanoma (MM) or Renal Cell Carcinoma (RCC). J. Clin. Oncol. 2009, 27, 3024. [CrossRef]

223. Gillessen, S.; Gnad-Vogt, U.S.; Gallerani, E.; Beck, J.; Sessa, C.; Omlin, A.; Mattiacci, M.R.; Liedert, B.; Kramer, D.; Laurent, J.; et al. A Phase i Dose-Escalation Study of the Immunocytokine EMD 521873 (Selectikine) in Patients with Advanced Solid Tumours. Eur. J. Cancer 2013, 49, 35-44. [CrossRef]

224. Strauss, J.; Heery, C.R.; Kim, J.W.; Jochems, C.; Donahue, R.N.; Montgomery, A.S.; McMahon, S.; Lamping, E.; Marte, J.L.; Madan, R.A.; et al. First-in-Human Phase I Trial of a Tumor-Targeted Cytokine (NHS-IL12) in Subjects with Metastatic Solid Tumors. Clin. Cancer Res. 2019, 25, 99-109. [CrossRef]

225. van den Heuvel, M.M.; Verheij, M.; Boshuizen, R.; Belderbos, J.; Dingemans, A.M.C.; De Ruysscher, D.; Laurent, J.; Tighe, R.; Haanen, J.; Quaratino, S. NHS-IL2 Combined with Radiotherapy: Preclinical Rationale and Phase Ib Trial Results in Metastatic Non-Small Cell Lung Cancer Following First-Line Chemotherapy. J. Transl. Med. 2015, 13, 1-13. [CrossRef] [PubMed]

226. Kaufman, H.L.; Mehnert, J.M.; Cuillerot, J.-M.; von Heydebreck, A.; Ott, P.A.; Hodi, F.S. Targeted Modified IL-2 (NHS-IL2, MSB0010445) Combined with Stereotactic Body Radiation in Advanced Melanoma Patients after Progression on Ipilimumab: Assessment of Safety, Clinical, and Biologic Activity in a Phase 2a Study. J. Clin. Oncol. 2014, 32, TPS9107. [CrossRef]

227. Kim, J.W.; Heery, C.R.; Bilusic, M.; Singh, N.K.; Madan, R.A.; Sabzevari, H.; Schlom, J.; Gulley, J.L. First-in-Human Phase I Trial of NHS-IL12 in Advanced Solid Tumors. J. Clin. Oncol. 2012, 30, TPS2617. [CrossRef]

228. Van Brummelen, E.M.J.; Huisman, M.C.; de Wit-van der Veen, L.J.; Nayak, T.K.; Stokkel, M.P.M.; Mulder, E.R.; Hoekstra, O.S.; Vugts, D.J.; Van Dongen, G.A.M.S.; Verheul, H.M.; et al. 89Zr-Labeled CEA-Targeted IL-2 Variant Immunocytokine in Patients with Solid Tumors: CEA-Mediated Tumor Accumulation and Role of IL-2 Receptor-Binding. Oncotarget 2018, 9, 24737-24749. [CrossRef]

229. Schellens, J.H.M.; Tabernero, J.; Lassen, U.N.; Melero, I.; Homicsko, K.; Argilés, G.; Perez Gracia, J.L.; Sorensen, M.; Coukos, G.; ANGEVIN, E.; et al. CEA-Targeted Engineered IL2: Clinical Confirmation of Tumor Targeting and Evidence of Intra-Tumoral Immune Activation. J. Clin. Oncol. 2015, 33, 3016. [CrossRef]

230. Bachanova, V.; Lansigan, F.; Quick, D.P.; Vlock, D.; Gillies, S.; Nakamura, R. Remission Induction in a Phase I/II Study of an Anti-CD20-Interleukin-2 Immunocytokine DI-Leu16-IL2 in Patients with Relapsed B-Cell Lymphoma. Blood 2015, 126, 153. [CrossRef]

231. Lansigan, F.; Nakamura, R.; Quick, D.P.; Vlock, D.; Raubitschek, A.; Gillies, S.D.; Bachanova, V. DI-Leu16-IL2, an Anti-CD20Interleukin-2 Immunocytokine, Is Safe and Active in Patients with Relapsed and Refractory B-Cell Lymphoma: A Report of Maximum Tolerated Dose, Optimal Biologic Dose, and Recommended Phase 2 Dose. Blood 2016, 128, 620. [CrossRef]

232. Lansigan, F.; Nakamura, R.; Quick, D.; Vlock, D.; Raubitschek, A.A.; Gillies, S.D.; Bachanova, V. Phase I/II Study of an AntiCD20-Interleukin-2 Immunocytokine DI-Leu16-IL2 in Patients with Relapsed b-Cell Lymphoma (NHL). J. Clin. Oncol. 2016, 34, e19046. [CrossRef]

233. Soerensen, M.M.; Ros, W.; Rodriguez-Ruiz, M.E.; Robbrecht, D.; Rohrberg, K.S.; Martin-Liberal, J.; Lassen, U.N.; Melero Bermejo, I.; Lolkema, M.P.; Tabernero, J.; et al. Safety, PK/PD, and Anti-Tumor Activity of RO6874281, an Engineered Variant of Interleukin2 (IL-2v) Targeted to Tumor-Associated Fibroblasts via Binding to Fibroblast Activation Protein (FAP). J. Clin. Oncol. 2018, 36, e15155. [CrossRef] 